\title{
Transports and Pathways of the Upper-Layer Circulation in the Western Tropical Atlantic
}

\author{
Friedrich A. Schott, JÜrgen Fischer, AND Lothar Stramma \\ Institut für Meereskunde an der Universität Kiel, Kiel, Germany
}

(Manuscript received 17 July 1997, in final form 4 December 1997)

\begin{abstract}
The mean warm water transfer toward the equator along the western boundary of the South Atlantic is investigated, based on a number of ship surveys carried out during 1990-96 with CTD water mass observations and current profiling by shipboard and lowered (with the CTD/rosette) acoustic Doppler current profiler and with Pegasus current profiler. The bulk of the northward warm water flow follows the coast in the North Brazil Undercurrent (NBUC) from latitudes south of $10^{\circ} \mathrm{S}$, carrying $23 \mathrm{~Sv}\left(\mathrm{~Sv} \equiv 10^{6} \mathrm{~m}^{3} \mathrm{~s}^{-1}\right)$ above $1000 \mathrm{~m}$. Out of this, $16 \mathrm{~Sv}$ are waters warmer than $7^{\circ} \mathrm{C}$ that form the source waters of the Florida Current. Zonal inflow from the east by the South Equatorial Current enters the western boundary system dominantly north of $5^{\circ} \mathrm{S}$, adding transport northwest of Cape San Roque, and transforming the NBUC along its way toward the equator into a surface-intensified current, the North Brazil Current (NBC). From the combination of moored arrays and shipboard sections just north of the equator along $44^{\circ} \mathrm{W}$, the mean NBC transport was determined at $35 \mathrm{~Sv}$ with a small seasonal cycle amplitude of only about $3 \mathrm{~Sv}$. The reason for the much larger near-equatorial northward warm water boundary current than what would be required to carry the northward heat transport are recirculations by the zonal current system and the existence of the shallow South Atlantic tropical-subtropical cell (STC). The STC connects the subduction zones of the eastern subtropics of both hemispheres via equatorward boundary undercurrents with the Equatorial Undercurrent (EUC), and the return flow is through upwelling and poleward Ekman transport. The persistent existence of a set of eastward thermocline and intermediate countercurrents on both sides of the equator was confirmed that recurred throughout the observations and carry ventilated waters from the boundary regime into the tropical interior. A strong westward current underneath the EUC, the Equatorial Intermediate Current, returns low-oxygen water westward. Consistent evidence for the existence of a seasonal variation in the warm water flow south of the equator could not be established, whereas significant seasonal variability of the boundary regime occurs north of the equator: northwestward alongshore throughflow of about $10 \mathrm{~Sv}$ of waters with properties from the Southern Hemisphere was found along the Guiana boundary in boreal spring when the North Equatorial Countercurrent is absent or even flowing westward, whereas during JuneJanuary the upper NBC is known to connect with the eastward North Equatorial Countercurrent through a retroflection zone that seasonally migrates up and down the coast and spawns eddies. The equatorial zone thus acts as a buffer and transformation zone for cross-equatorial exchanges, but knowledge of the detailed pathways in the interior including the involved diapycnal exchanges is still a problem.
\end{abstract}

\section{Introduction}

The thermohaline circulation of the Atlantic Ocean and associated heat transport imply a meridional overturning cell of some $17 \mathrm{~Sv}\left(\mathrm{~Sv} \equiv 10^{6} \mathrm{~m}^{3} \mathrm{~s}^{-1}\right.$ : e.g., Wunsch 1984; Gordon 1986; Schmitz 1995). Until recently, very little was known about the pathways in the equatorial zone of either the northward warm water transfer or the return flow of cold North Atlantic Deep Water. New evidence showing complex pathways of the deep circulation as it interacts with the equator has been provided in the past several years (Richardson and Schmitz 1993; Schott et al. 1993; Rhein et al. 1995;

Corresponding author address: Dr. Friedrich A. Schott, Institut für Meereskunde, Universität Kiel, Düternbrooker Weg 20, 24105 Kiel, Germany.

E-mail: fschott@ifm.uni-kiel.de
Friedrichs and Hall 1993). Here, the currents and transports associated with the warm water inflow from the Southern Hemisphere into the western tropical Atlantic boundary regime will be investigated, using observations collected as part of the World Ocean Circulation Experiment (WOCE) by a variety of shipboard methods in the boundary regime between $10^{\circ} \mathrm{S}$ along the Brazil coast to $44^{\circ} \mathrm{W}$ and by a moored array in the cross-equatorial boundary flow.

The known warm water circulation in this region includes the North Brazil Current (NBC) as its western boundary current, carrying warm water of South Atlantic origin across the equator. Contributors to the NBC are zonal inflows from the east in the latitude range of $6^{\circ} \mathrm{S}-3^{\circ} \mathrm{N}$ by the South Equatorial Current (SEC) as well as boundary flow along the Brazilian coast originating south of $10^{\circ} \mathrm{S}$ (Stramma et al. 1995; Schott et al. 1995). Zonal outflows that draw water masses away into the 
the interior are the Equatorial Undercurrent (EUC), the North and South Equatorial Undercurrents (NEUC, SEUC) in latitude ranges $3^{\circ}-5^{\circ}$ of either side of the equator, and the North Equatorial Countercurrent (NECC). How the northward net transfer of warm water passes through this complex current system is still very much unknown, both as regards the overall mean and the annual cycle.

Direct transport measurements are scarce and geostrophic estimates of the near-equatorial currents are unreliable. The NBC transport past the equator at $44^{\circ} \mathrm{W}$ was estimated from a moored array by Schott et al. (1993). They obtained an annual mean of $24 \mathrm{~Sv}$ in the upper $300 \mathrm{~m}$ with only a small seasonal cycle of not more than $10 \%$ superimposed. Similarly, indications of annual variations are small for the SEC south of the equator, both in ship drifts (Arnault 1987) and from altimetry (Stammer and Wunsch 1994). The largest annual cycle of the region is associated with the western part of the NECC, which has its maximum eastward transport in late northern summer and its minimum, with the flow even reversing to westward, in spring (Richardson and Reverdin 1987; Didden and Schott 1992).

It was earlier assumed that this large seasonality, coupled with less variable flow across the equator, meant enhanced transport along the boundary toward the $\mathrm{Ca}$ ribbean in late winter (Richardson and Philander 1987), but the evidence for such enhanced flow along the boundary during winter is not clear as of yet. What has been determined is that much of the transfer of Southern Hemispheric water mass along the boundary toward the Caribbean occurs through eddy shedding from the NBC/ NECC retroflection zone (Johns et al. 1993; Didden and Schott 1993; Richardson et al. 1994). It still remains to be determined where part of the cross-equatorial NBC flow remains during the period when the NECC is weak or even westward.

Significant feeding into the NECC and NEUC also comes from the north, through recirculation of water masses out of the North Equatorial Current (NEC) (Wilson et al. 1994), which is in agreement with deductions from the high resolution Community Modeling Effort (CME) model (Schott and Böning 1991). Part of this Northern Hemispheric equatorward inflow is carried by a newly discovered coastal undercurrent (Wilson et al. 1994), the Guiana Undercurrent (GUC), that was earlier postulated from analysis of the CME model (Schott and Böning 1991). As a Southern Hemispheric counterpart, it was found both in that CME model evaluation and in recent observations (Stramma et al. 1995; Schott et al. 1995) that the northward flow along the coast of Brazil between $5^{\circ}$ and $10^{\circ} \mathrm{S}$ occurs as an undercurrent, the North Brazil Undercurrent (NBUC). This undercurrent has its velocity maximum of $80 \mathrm{~cm} \mathrm{~s}^{-1}$ at about 200-m depth, whereas near-surface currents are weak or even southward. It gains only little inflow from the east between $10^{\circ}$ and $5^{\circ} \mathrm{S}$. Only after turning around Cape San Roque, near $5^{\circ} \mathrm{S}$, when it is overlayed by the west- ward-flowing surface-intensified SEC does the NBUC lose its undercurrent character and is then called the NBC.

The total meridional warm water flow in the nearequatorial boundary current exceeds the required Atlantic meridional overturning rate of some $17 \mathrm{~Sv}$ substantially. The reason is that three thermohaline cells exist near the equator. First, there is the top-to-bottom conveyor belt circulation. The second cell is the shallow tropical-subtropical cell (STC). The STC connects the subduction regions of the eastern subtropics with the EUC and equatorial upwelling, from where the water returns poleward in the tropical interior. Finally, there is the tropical cell (TC) in which part of the equatorial divergence is subducted at near-equatorial latitues by Ekman convergence and returns to the EUC in the interior (e.g., Bryden and Brady 1985).

For the STC it is argued that potential vorticity conservation prevents the subducted water from linking with the equatorial zone in the interior of the ocean but that it has to flow westward first, feeding equatorward undercurrents along the western boundary (e.g., Pedlosky 1987; McCreary and Lu 1994; Liu et al. 1994). In the tropical Atlantic, these equatorward undercurrents would be the NBUC and the GUC. However, as recently pointed out by $\mathrm{Lu}$ et al. (1998), the model evidence regarding the pathways of the STC is unclear. While layer models have wide eastern shadow zones between the subtropical subduction zones and the equatorial regime, thus forcing the equatorward thermocline flow to entirely pass through the western undercurrents, standard GCMs allow considerable meridional inflow toward the equator also in the ocean's interior.

With the Ekman divergence between $8^{\circ} \mathrm{N}$ and $8^{\circ} \mathrm{S}$ accounting for an upwelling of some $25 \mathrm{~Sv}$ (Roemmich 1983), the TC and STC are important factors in the nearequatorial thermohaline circulation. As regards specifically the equatorward warm water circulation of the western tropical South Atlantic, presumably only the STC has the potential of contributing significantly, whereas the TC is an oceanwide interior overturning roll.

Underneath the thermocline waters, northward propagation of Antarctic Intermediate Water (AAIW) occurs in the western tropical Atlantic (Tsuchiya 1989), and the salinity minimum and oxygen maximum associated with it was found to connect with the eastward lowlatitude Northern and Southern Intermediate Countercurrents (NICC, SICC) on both sides of the equator (Schott et al. 1995). This will be the deepest layer dealt with in the present analysis. Below it still, there are remnants of lower oygen, higher salinity waters-the Upper Circumpolar Water-which are swept toward the equator with the deeper part of the NBUC, but which we will not specifically address here.

A number of individual ship surveys with R/V Meteor were carried out in the boundary region between $10^{\circ} \mathrm{S}$ and several degrees north of the equator during 1990- 


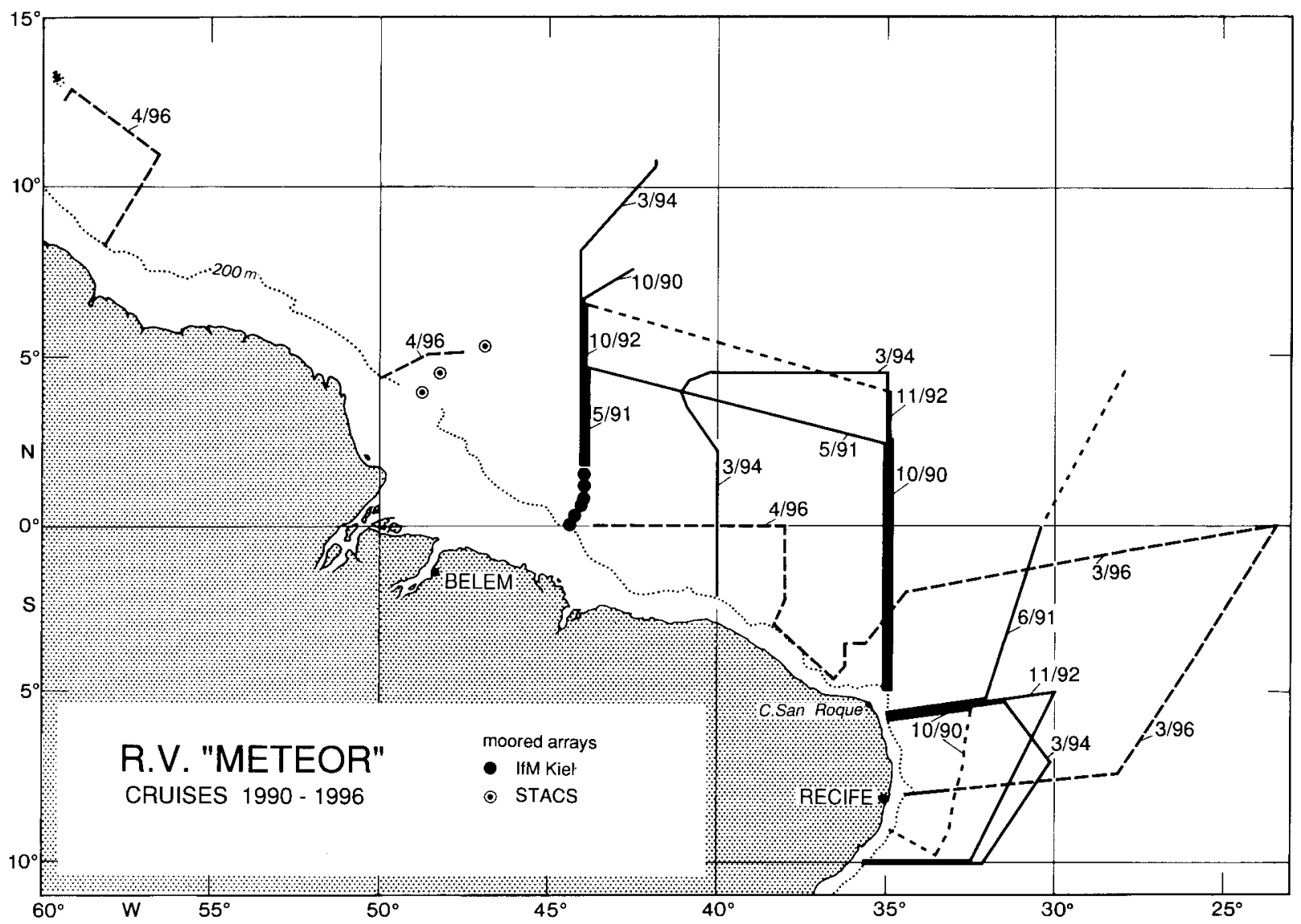

FIG. 1. Section map of the region; cruise tracks are identified by month/year; solid lines for sections with CTD/LADCP stations, and dashed lines for sections with shipboard ADCP only. Moored array locations of IfM Kiel along $44^{\circ} \mathrm{W}$ and of Johns et al. (1998) (STACS) are also shown.

96. Analyses of individual surveys have been presented by Stramma et al. (1995) for the $5^{\circ}-10^{\circ} \mathrm{S}$ range of $\mathrm{Me}$ teor cruise M22/2 in November 1992 and by Schott et al. (1995) for Meteor cruise M27/3 in March 1994. These will be referred to here in abbreviated form.

Shipboard acoustic Doppler current profiler (ADCP) measurements of upper-layer currents were carried out and deeper profiles were obtained aboard the Meteor by Pegasus profiler and by lowered ADCP (LADCP), where the ADCP was strapped to the CTD rosette ( $\mathrm{Fi}$ scher and Visbeck 1993). Water masses are being traced by their salinity and oxygen distributions along core isopycnal surfaces to determine pathways. We will present current patterns for near-surface and subthermocline flows, marked by their water mass characteristics. Transports will be calculated for isopycnal layers of the individual current branches, and from the different surveys we can establish confidence bars for these transport estimates.

As regards transports, the best-measured section was the $44^{\circ} \mathrm{W}$ meridian with the Meteor sections complemented by several moored arrays along that section. Compared to the earlier moored transport determina- tions of Schott et al. (1993), we have now a better instrument coverage for the depth range $300 \mathrm{~m}-600 \mathrm{~m}$; that is, below the near-surface ADCPs, for which the earlier transport estimates had to be mainly based on interpolation. It is interesting to note that with the availability of yet additional current meter data compared to the database of Schott et al. (1993), the evidence for an annual cycle of the cross-equatorial NBC transport is reduced, not substantiated.

Figure 1 shows how the individual standard sections were covere by these various cruises and also the mooring positions at $44^{\circ} \mathrm{W}$ from which time series are used in this analysis.

\section{Observations and methods}

\section{a. Hydrography}

Repeat sections for the Meteor surveys were $44^{\circ} \mathrm{W}$, $35^{\circ} \mathrm{W}$, and $5^{\circ} \mathrm{S}$ (Fig. 1), where Pegasus transponder pairs were deployed. Hydrographic measurements on Meteor cruises M14/2 (Oct 1990), M16/3 (May-Jun 1991), M22/2 (Oct-Nov 1992), and M27/3 (Mar 1994) were 
carried out with a Neil Brown MkIII CTD combined with rosette sampling and protected/unprotected thermometer measurements. The CTD temperature and conductivity sensors were laboratory-calibrated prior to and after each cruise. Temperature accuracy is estimated at $\pm 0.003^{\circ} \mathrm{C}$, and salinity accuracy at \pm 0.003 . On cruise M34/4, March-April 1996, a Sea-Bird Electronics 19 CTD was used with laboratory calibration but without further bottle sample calibrations.

Oxygen measurements were carried out on all Meteor cruises. Accuracy of the calibrated oxygen data of the Meteor cruises is estimated at $\pm 0.1 \mathrm{ml} \mathrm{l}^{-1}$ except for M14/2 where it was reduced to $\pm 0.25 \mathrm{ml}^{-1}$. For M34/ 4 no oxygen calibration was possible and the data are not used. In between CTD stations and on transit legs between CTD sections XBT casts were carried out on the Meteor cruises. Based on a temperature-salinity relation, they were also used for geostrophic transport calculations (Stramma et al. 1995), but with not much success for the transports of the western boundary current.

\section{b. Current profiling}

For current profiling, three systems were used. Shipboard ADCP profiling of the near-surface layers was carried out by a $153.6-\mathrm{kHz}$ RD-Instruments system. The depth range was about $400 \mathrm{~m}$ during M27/3 and somewhat less during M16/3 and M22/2, with the range being quite dependent on sea state; the range was $<200 \mathrm{~m}$ if the ship headed into heavier weather. During M14/2 the built-in shipboard transducer went defunct and a 150$\mathrm{kHz}$ self-contained ADCP was built into the ship's well with a makeshift holding frame. Several times the unit had to be taken out to read the data out and repair damage caused by vibration. Since cruise M16/3 was on the Meteor return voyage from the South Atlantic following cruise M14, the shipboard transducer was still not fixed, but this time a $150-\mathrm{kHz}$ transducer for shipboard use was brought along and built into the well. These transducer exchanges during and in between cruises made several measurements of the transducer misalignment angle necessary. On the subsequent two Meteor cruises the built-in ADCP worked well and on M27/3 it had a better range because a protective cover above it was removed. On all four cruises ADCP absolute currents were determined by using standard shipboard gyro-heading and navigation from the global positioning system (GPS). During M27/3 a gyro problem caused direction biasses, which had to be compensated individually for each section and led to somewhat larger errors (Schott et al. 1995).

Recently, participation on a Meteor cruise (M34/4) in March 1996 complemented the measurements in the study area and, in particular, provided quasisynoptic coverage of the northwestern boundary regime (Fig. 1). The measurements consisted of upper-layer current ob- servations by shipboard ADCP and some CTD stations as a piggyback operation during a geology cruise.

As a second profiling method and the only deep method that routinely worked at the beginning of the field studies, the Pegasus profiler was used at a subset of stations along $44^{\circ} \mathrm{W}, 35^{\circ} \mathrm{W}$, and $5^{\circ} \mathrm{S}$ (Rhein et al. 1995).

The third method, application of a self-contained ADCP attached to the CTD/rosette frame for deep profiling, was first used on M14/2 in a trial mode and routinely on the subsequent cruises. By that method, the current shears recorded by the ADCP are strapped together piecewise to obtain an overall shear profile (Fischer and Visbeck 1993). Comparison with shears derived from Pegasus current profiles at joint stations showed the generally acceptable quality of the LACDP profiles. The vertically integrated shear profiles were subsequently referenced by GPS positioning to obtain absolute currents. Problems were initial leakage of transducers that cracked under the repeated change of pressure (since corrected by the manufacturers) and low range at great depth where it is not clear whether this has merely to be attributed to low concentration of scatterers or whether pressure effects on the ADCP transducer also play a role.

In the present analysis, the shipboard and lowered ADCP data are merged with the Pegasus profiles to a joint product. Mapping scales are $50 \mathrm{~m}$ vertically and $20 \mathrm{~km}$ horizontally.

\section{c. Moorings along $44^{\circ} \mathrm{W}$}

Along $44^{\circ} \mathrm{W}$ several arrays of moored current meters and ADCPs had been deployed during 1989-94 (Fig. 1). An analysis of the first set of records was given in Schott et al. (1993). The mean of the NBC had been determined from three ADCPs at $24 \mathrm{~Sv}$ for the upper $300 \mathrm{~m}$ and a small, of only $O(10 \%)$, seasonal cycle was detected on the background of energetic fluctuations of several weeks period. Those observations suffered, particularly from a lack of coverage at the level of the AAIW, and the 300-1000 m transport estimates could only be based on ship sections and mooring interpolation. Here we include additional data from an array deployed during 1993-94 that again included three ADCPs, and we merge these different datasets into a time series of interpolated monthly means.

\section{Warm water masses of the southwestern tropical Atlantic}

\section{a. The salinity-maximum layer}

A composite $\Theta-S$ diagram of the seasonal profiles from the Levitus (1982) dataset for three subregions of the western tropical Atlantic is shown in Fig. 2. They are from the South Atlantic inflow region off Brazil, from the western equatorial zone, and from the northwestern tropical regime. When referring to northern sa- 


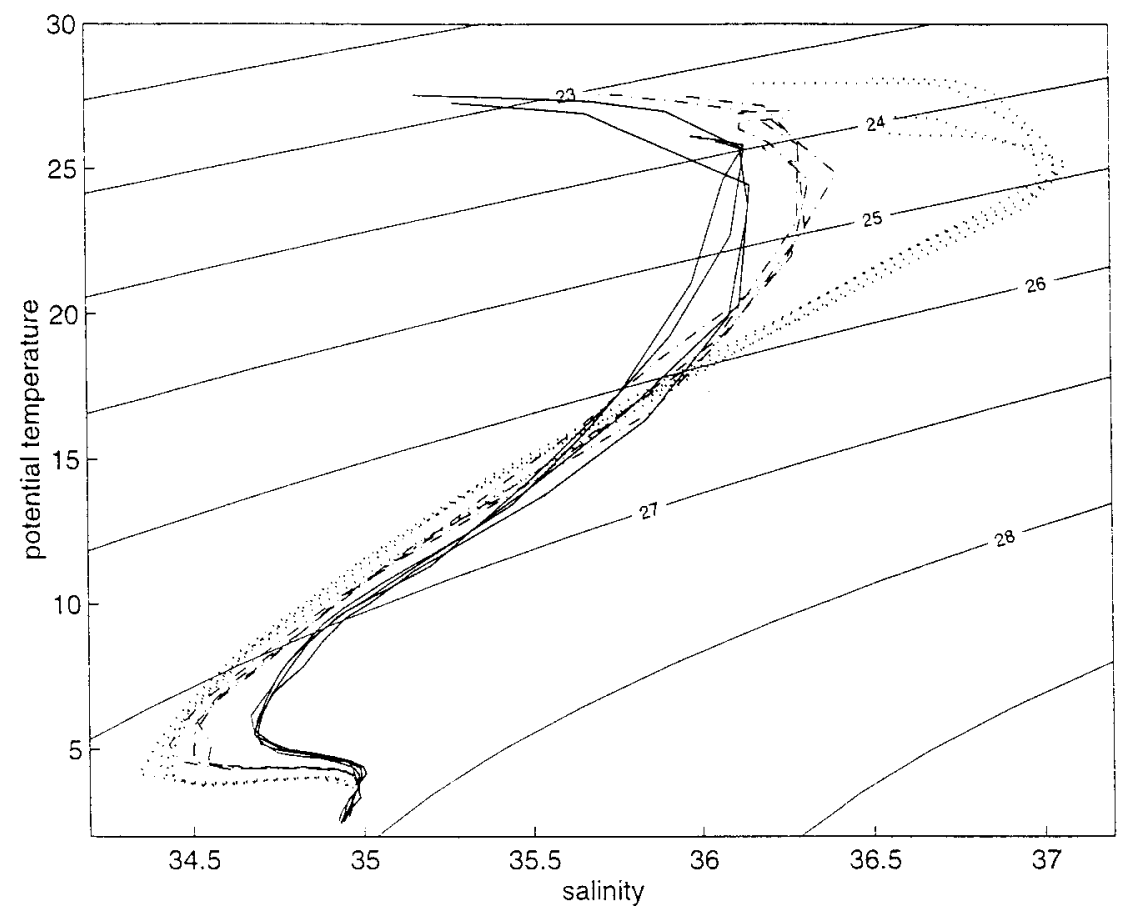

FIG. 2. $\Theta-S$ diagram from Levitus data for the the four seasons at $9.5^{\circ} \mathrm{N}, 41.5^{\circ} \mathrm{W}$ (solid lines); at $0.5^{\circ} \mathrm{S}, 41.5^{\circ} \mathrm{W}$ (dash-dots); and at $10.5^{\circ} \mathrm{S}, 35.5^{\circ} \mathrm{W}$ (dots).

linities in the following it will be those from the northwestern regime. The top layer of our study region, only $50-100 \mathrm{~m}$ thick, is made up by tropical surface water (Csanady 1987) of temperatures exceeding $26^{\circ} \mathrm{C}$ (Fig. $3)$. In the upper part of the thermocline, water masses in the inflow region along the boundary at $5^{\circ}-10^{\circ} \mathrm{S}$ are characterized by a near-surface salinity maximum at $\sigma_{\Theta}$ $=25.0$ (Fig. 2) that exceeds a salinity of 37.0 psu in the southern inflow region (Fig. 3). This layer is ventilated in the central subtropical South Atlantic and begins to reach the surface at the western end of the $10^{\circ} \mathrm{S}$ section of our survey region (Fig. 3). The salinity-maximum water is prominent along the boundary near Cape San Roque (Fig. 4) and again, with reduced peak value, along the $35^{\circ} \mathrm{W}$ section at the equator (Fig. 4). It thus serves to trace the Southern Hemispheric supply route of the EUC.

At $44^{\circ} \mathrm{W}$ the salinity maximum along the boundary is still present, though reduced against the southern inflow regime. The Northern Hemispheric salinity maximum is weaker, at only $36.5-36.7 \mathrm{psu}$ in individual profiles of our study area and at 36.0 psu in the Levitus data (Fig. 2). It occurs at somewhat lower densities in the Levitus data, but at higher densities in actual individual profiles of our surveys. As it is passed toward the equator by the NEC and the Guiana Undercurrent (Wilson et al. 1994), it is not distinguishable from the southern maximum by its core density, and double maxima due to overlaying water masses of both hemispheres are not observed. North of the equator, where the south- ern maximum is reduced to the same magnitude as the northern one, we have thus the occurrence of similar maxima for both origins.

In oxygen, the salinity-maximum layer is a gradient layer in most of the region, with higher values protruding in from the south along the North Brazilian coast. Metcalf and Stalcup (1967), tracing oxygen at the EUC core level, were the first to demonstrate that the source of the EUC should exclusively be in the Southern Hemisphere. Their oxygen map suggests that the EUC is supplied by the NBC via a retroflection that reaches across $44^{\circ} \mathrm{W}$ to near $3^{\circ} \mathrm{N}$. This was confirmed in the spring 1994 survey of Schott et al. (1995), who showed that the location of the EUC retroflection was west of $44^{\circ} \mathrm{W}$ where part of the NBC turned eastward to feed the EUC.

As in Schott et al. (1995) we present property distributions on the isopycnic surface $\sigma_{\Theta}=25.0$ to describe the salinity-maximum water. Southern inflow stations at $5^{\circ}-10^{\circ} \mathrm{S}$ are characterized by high oxygens of $4.5-5.1$ $\mathrm{ml} \mathrm{l}^{-1}$ in the NBC near the coast combined with high salinities.

In the northern offshore boundary regime, south of $10^{\circ} \mathrm{N}$, recirculation water out of the NEC dominates at this isopycnal level, with oxygens of generally $<4.0 \mathrm{ml}$ $1^{-1}$ combined with salinities $<36.5$ psu. At times, the mixed layer in the northern regime can penetrate to the $\sigma_{\Theta}=25.0$ level, thus distorting the water mass tracing.

In the property distributions, stations are marked by solid dots for waters that are of southern origin, defined by $\mathrm{S}>36.6 \mathrm{psu}, \mathrm{O}_{2}>4.0 \mathrm{ml} \mathrm{l}^{-1}$, and of north equatorial 

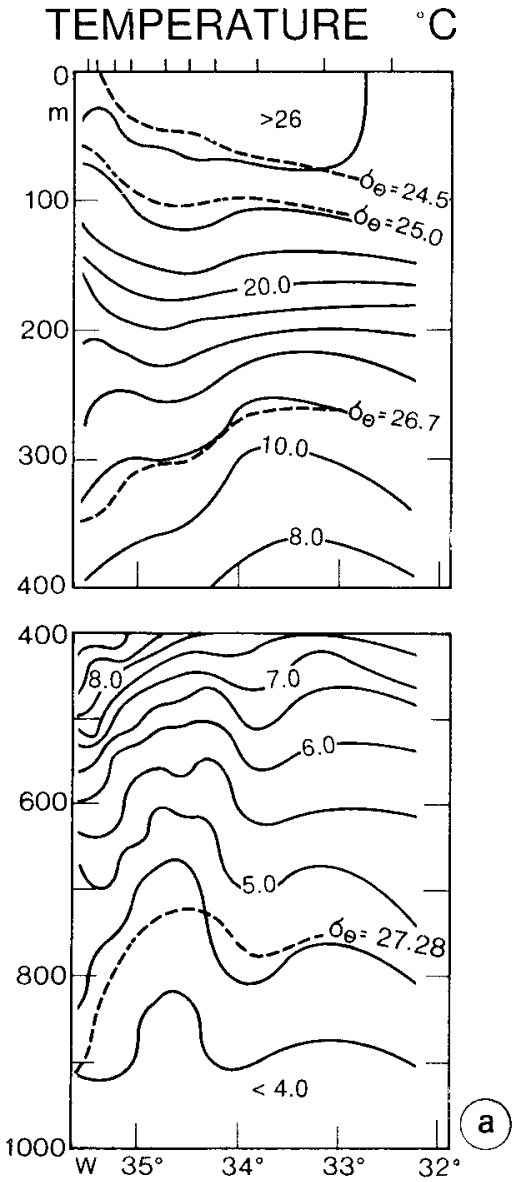
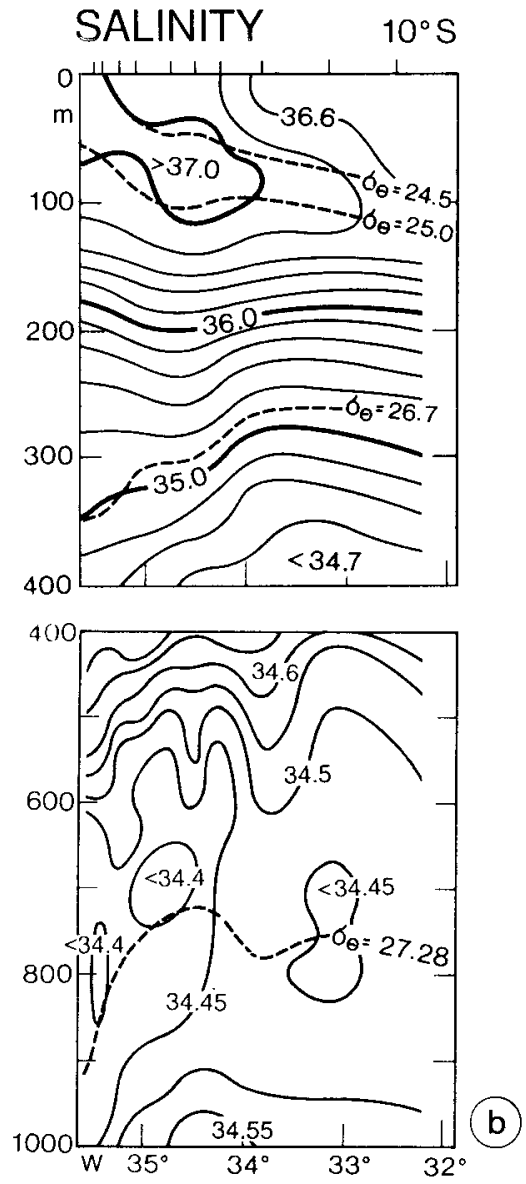
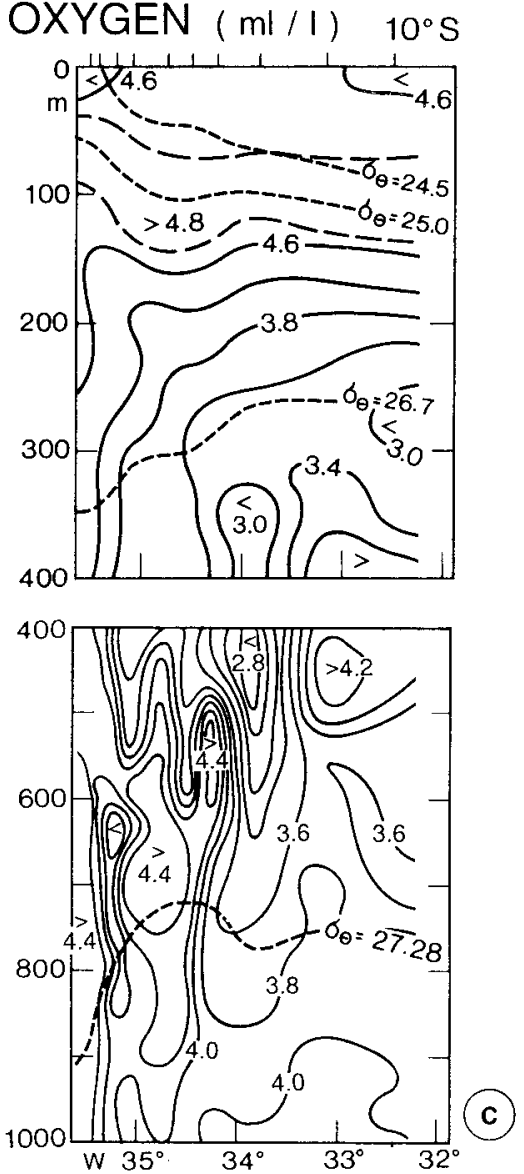

FIG. 3. Section of potential temperature (a), salinity (b), and oxygen (c) at $10^{\circ} \mathrm{S}$ from Meteor cruise M22/2 (November 1992 ).

origin defined by $\mathrm{S}<36.6 \mathrm{psu}, \mathrm{O}_{2}<4.3 \mathrm{ml} 1^{-1}$. However, as resulting from the previous paragraphs, diluted waters with properties typical for the Southern Hemisphere cannot be clearly distinguished from resident northern waters, as we will see when discussing the patterns. Currents measured by shipboard and lowered ADCPs are shown as vector plots in conjunction with the water mass distributions.

\section{b. The subthermocline layer}

Below the salinity-maximum water, beginning at $\sigma_{\Theta}$ $=26.0$, the $\Theta-S$ curve is near-linear and very tight for the Southern Hemispheric inflow, representative of South Atlantic Central Water (Fig. 2). That also applies to the water from $44^{\circ} \mathrm{W}$ near the boundary and to the equatorial belt, suggesting propagation of southern water masses along the boundary to the equator. The stations from north of the equator show a much wider spreading of the $\Theta-S$ relation, suggesting mixing and interleaving of southern and northern subthermocline waters along the boundary.

The deeper waters of the upper layer, relating to the off-equatorial undercurrents, can be traced by their ox- ygen concentrations and salinities along $\sigma_{\Theta}=26.7$. This isopycnal, located slightly below the $1.4 \mathrm{~cm}^{3} \mathrm{~kg}^{-1}$ isanosteric surface of Tsuchiya (1986), has a depth of 300 $\mathrm{m}$ in the core of the NBUC off Brazil at $10^{\circ} \mathrm{S}$ (Fig. 3), between 200 and $260 \mathrm{~m}$ in the western equatorial region (Fig. 4), and shoals slightly to the north. It approaches the center of the equatorial $13^{\circ} \mathrm{C}$ thermostad (Tsuchiya 1986) and is also near the velocity cores of both the SEUC and NEUC (Schott et al. 1995). The salinity distribution of Tsuchiya (1986) on that surface shows a tongue of high salinities in the northern equatorial region, exceeding 35.8 psu, and spreading southwestward along the Guiana coast between $12^{\circ}$ and $6^{\circ} \mathrm{N}$, then feeding into an eastward wedge at $5^{\circ}-6^{\circ} \mathrm{N}$. South of the equator a salinity minimum of $35.2 \mathrm{psu}$ in his distribution spreads along the North Brazil coast and across the equator, with a wedge branching off eastward at the latitude of the SEUC.

In the oxygen distribution of Tsuchiya (1986), the highest values of $4 \mathrm{ml}^{-1}$ are observed at the NBUC level off North Brazil up to the equator, and from where a wedge exceeding $3.5 \mathrm{ml} \mathrm{l}^{-1}$ stretches eastward along the equator. A maximum exceeding $3 \mathrm{ml}^{-1}$ also extends along the SEUC axis over to the middle of the basin. 

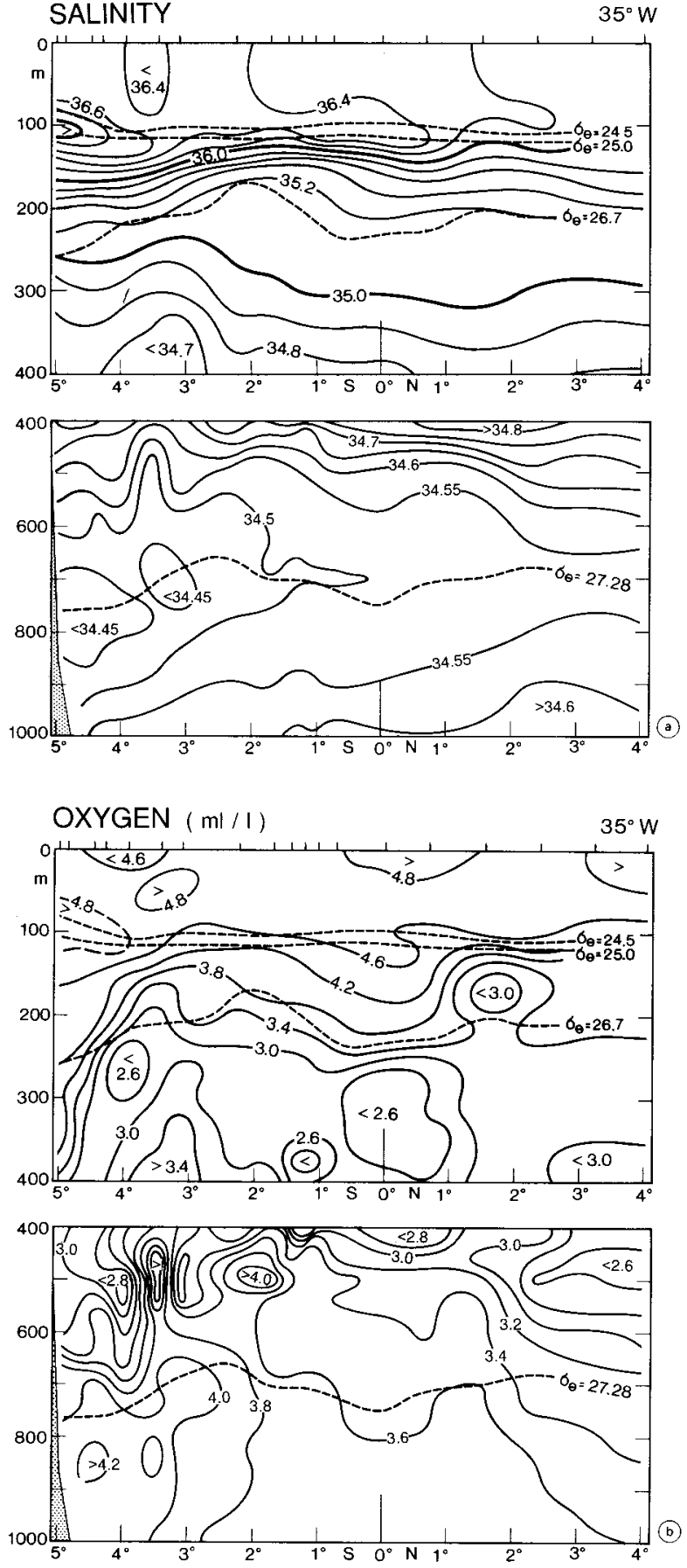

FIG. 4. Section of salinity (a) and oxygen (b) at $35^{\circ} \mathrm{W}$ from Meteor cruise M22/2 (November 1992).

Both the minimum in salinity and maximum in oxygen south of the equator in those maps can be traced back to the southeastern subtropical Atlantic off Namibia as their source region.

Similarly, the northern tropical maxima of both properties relate back to the northeastern subtropical North Atlantic off West Africa. Similar conclusions regarding the southeastern origin of water masses in this isopycnal range can be drawn from the property distributions of Reid (1989) on the surface $\sigma_{\Theta}=26.75$ that lies $30-70$ $\mathrm{m}$ deeper at the equator, at the bottom of the $13^{\circ} \mathrm{C}$ water and also at the lower end of the NEUC and SEUC velocity cores.

In our study region, the southern source waters of the NBUC on $\sigma_{\Theta}=26.7$ have salinities $<35.2$ psu and oxygen contents $>4.0 \mathrm{ml} \mathrm{l}^{-1}$ (Fig. 3), whereas the waters of the SEC regime are characterized by lower oxygen (Fig. 4). These $\mathrm{O}_{2}$ gradients occur over a very small distance across the NBUC (Fig. 4). The water in the NEUC regime, at $44^{\circ} \mathrm{W}$, north of $2^{\circ} \mathrm{N}$, is a mixture of northern and equatorial waters. We mark southern waters on $\sigma_{\Theta}=26.7$ [similar to Schott et al. (1995)] by $\mathrm{S}<35.20, \mathrm{O}_{2}>3.4 \mathrm{ml} \mathrm{l}^{-1}$ (dots); equatorial waters by $\mathrm{S}<35.30, \mathrm{O}_{2}<3.3 \mathrm{ml} \mathrm{l}^{-1}$ (crosses); and northern waters by $\mathrm{S}>35.30, \mathrm{O}_{2}<3.3 \mathrm{ml}^{-1}$ (circles). Different from the $\sigma_{\Theta}=25.0$ level, at 26.7 the northern and southern core water masses are distinctly different, with lower salinities and higher oxygens entering from the south than available north of the equator.

Current measurements at the depth level of $\sigma_{\Theta}=26.7$ were near the bottom end of the ADCP range of the earlier Meteor cruises, resulting in some gaps for the vector plots shown for that level. For M14/2, where the shipboard ADCP range was about $200 \mathrm{~m}$ only, the combined LADCP/Pegasus data were used instead.

\section{c. The Antarctic Intermediate Water}

The Antarctic Intermediate Water (AAIW) spreads along the western boundary past the equatorial zone into the northern subtropics (Tsuchiya 1989). The AAIW salinity minimum of Fig. 2 is centered at about $\sigma_{\Theta}=$ 27.28 , corresponding to about $700 \mathrm{~m}$ near the equator. Water originating in the Southern Hemisphere can be traced on the core isopycnal by both the salinity minimum and the oxygen maximum. In the Tropics the oxygen maximum of the AAIW is observed only near the Brazilian coast and in an eastward wedge just south of the equator (Talley 1996).

The AAIW layer is below the range of the shipboard ADCP where we had more widely spaced profiles from the LADCP/Pegasus stations. Hence, the original current maps are noisier than those from the shipboard ADCP profiles further up, but the products shown are smoothed by the mapping applied. We distinguish here, as also done in Schott et al. (1995), southern waters with salinities below $34.50 \mathrm{psu}$ and oxygens exceeding $3.6 \mathrm{ml} \mathrm{l}^{-1}$ from northern waters with salinities higher and oxygens lower than these threshold marks.

Underneath the AAIW, there are extensions of saltier, oxygen-deficient Upper Circumpolar Deep Water $(\mathrm{CDW})$ that spread toward the equator in the western South Atlantic. Its core isopycnal is $\sigma_{2}=32.20$ at a depth of about $1300 \mathrm{~m}$ near $10^{\circ} \mathrm{S}$ (Reid 1989). We will, 
however, not distinguish this water class particularly in our analysis.

\section{Near-surface circulation in northern winter and spring}

North of the equator, one would expect certain changes of the near-surface circulation between the northern winter to spring season and the summer to fall season, due to the known strong seasonal cycle of the NECC. Maximum eastward NECC flow occurs in northern fall and weak eastward or even westward currents are observed in spring. In conjunction with these changes, variations in the cross-equatorial boundary flow and its further pathways in the Northern Hemisphere would be a consequence.

\section{a. March 1994, M27/3}

For details on this survey, which included, in addition to the standard sections of the other surveys, also a section along $40^{\circ} \mathrm{W}$ (Fig. 1), we refer to Schott et al. (1995). At the near-surface (Fig. 5a), the inflow into the western tropical boundary regime came dominantly from the east at low latitudes, crossing the $35^{\circ} \mathrm{W}$ meridian at $1^{\circ}-5^{\circ} \mathrm{S}$, but contributions also came from offshore at $5^{\circ}-10^{\circ} \mathrm{S}$, east of $35^{\circ} \mathrm{W}$. Currents and water mass properties corresponded in indicating partial supply of the upper part of the EUC from the south through the NBC retroflection, but admixtures of northern waters also contributed to the EUC. The dots at $5^{\circ}-9^{\circ} \mathrm{N}$ along the $44^{\circ} \mathrm{W}$ section may also be of diluted northern water type since these two cannot clearly be distinguished.

At $\sigma_{\Theta}=26.7$ (Fig. 5b), the NBUC was found to be near-continuous along the western boundary between $5^{\circ} \mathrm{S}$ and $10^{\circ} \mathrm{S}$, with almost no influx from the east. From the currents and water masses at the $35^{\circ} \mathrm{W}, 40^{\circ} \mathrm{W}$, and $44^{\circ} \mathrm{W}$ sections, Schott et al. (1995) concluded that the subsurface NBC was almost entirely retroflecting into the EUC, while the surface waters indicated a throughflow toward the northwest, the ultimate fate of which remained unclear, however. The SEUC, at $3^{\circ}-4^{\circ} \mathrm{S}$, is apparently not fed out of a NBUC retroflection near $5^{\circ} \mathrm{S}$, because its water masses differ from those in the NBUC core. The dots along $4^{\circ}-5^{\circ} \mathrm{N}$ indicate that southern waters out of the retroflection zone must have progressed there.

\section{b. May/June 1991, M16/3}

For the survey of spring 1991, the near-surface currents show again the connection between the westward SEC and NBUC inflow into the western equatorial regime, the NBC retroflection and then the EUC (Fig. 6a). The near-surface NBC is weak in this particular survey, and the north equatorial branch of the SEC is not recognizeable in the western part. The water mass distribution, marking water from the Southern Hemisphere
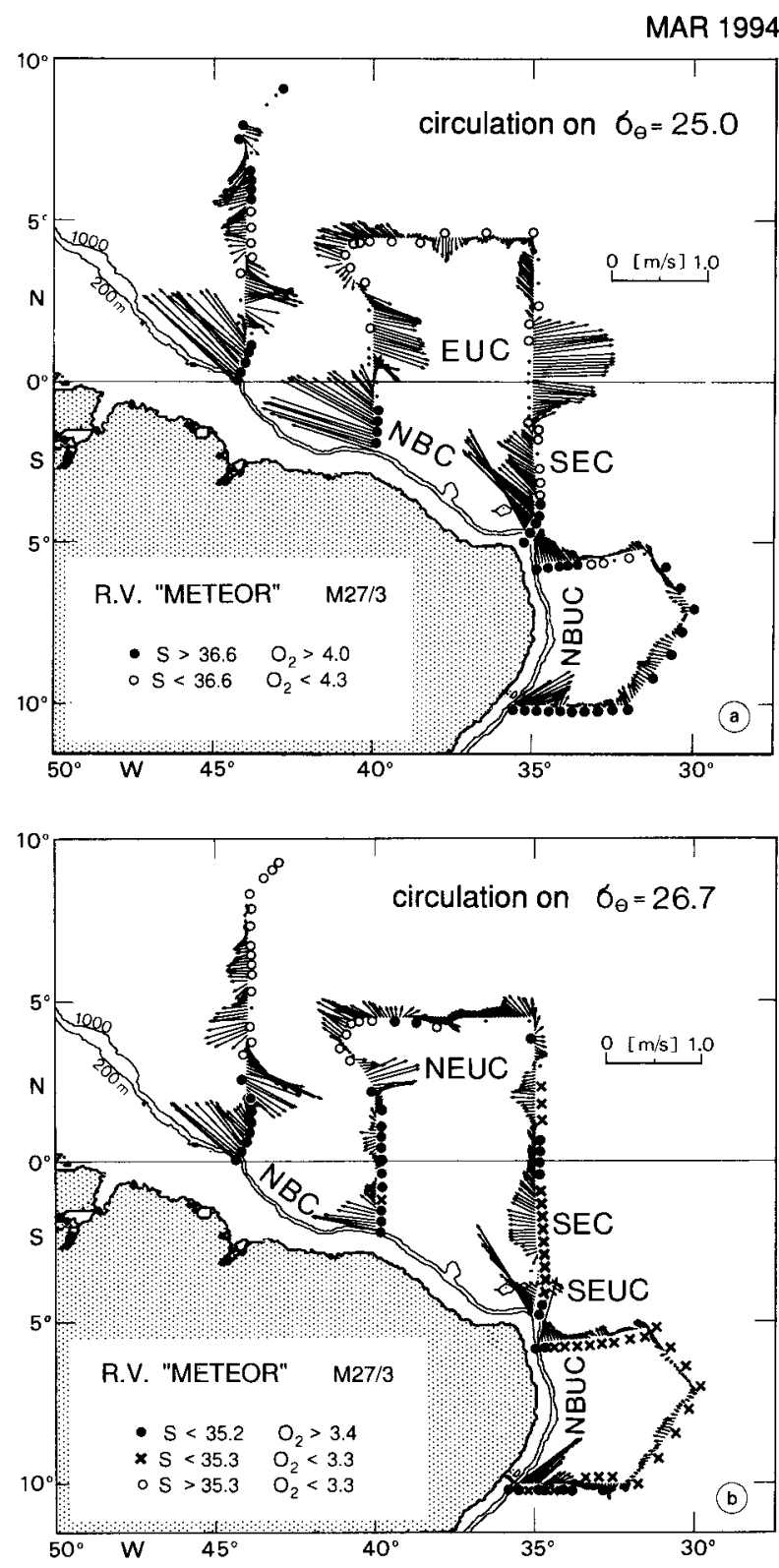

FIG. 5. Currents and water mass classes determined by $S-\mathrm{O}_{2}$ relations on $\sigma_{\Theta}$ surfaces (for details see legend and text; CTD stations that do not fall into the selected classes are marked by dots) during the March 1994 survey M27/3 for (a) $\sigma_{\Theta}=25.0$ and (b) $\sigma_{\Theta}=26.7$ (after Schott et al. 1995).

by oxygens $>4.0 \mathrm{ml} \mathrm{l}^{-1}$ and by salinities $>36.60 \mathrm{psu}$, confirms again the connection from the boundary current into the axis of the EUC.

At $\sigma_{\Theta}=26.7$, low-salinity, Southern Hemispheric water extends in a quasihomogeneous water body between $5^{\circ} \mathrm{S}$ and the equator without a boundary-current salinity signature. In oxygen content, however, the boundary flow at $5^{\circ} \mathrm{S}$ with $>3.4 \mathrm{ml} \mathrm{l}^{-1}$ is clearly distinguished from the interior waters of the south equatorial regime (Fig. 6b). 

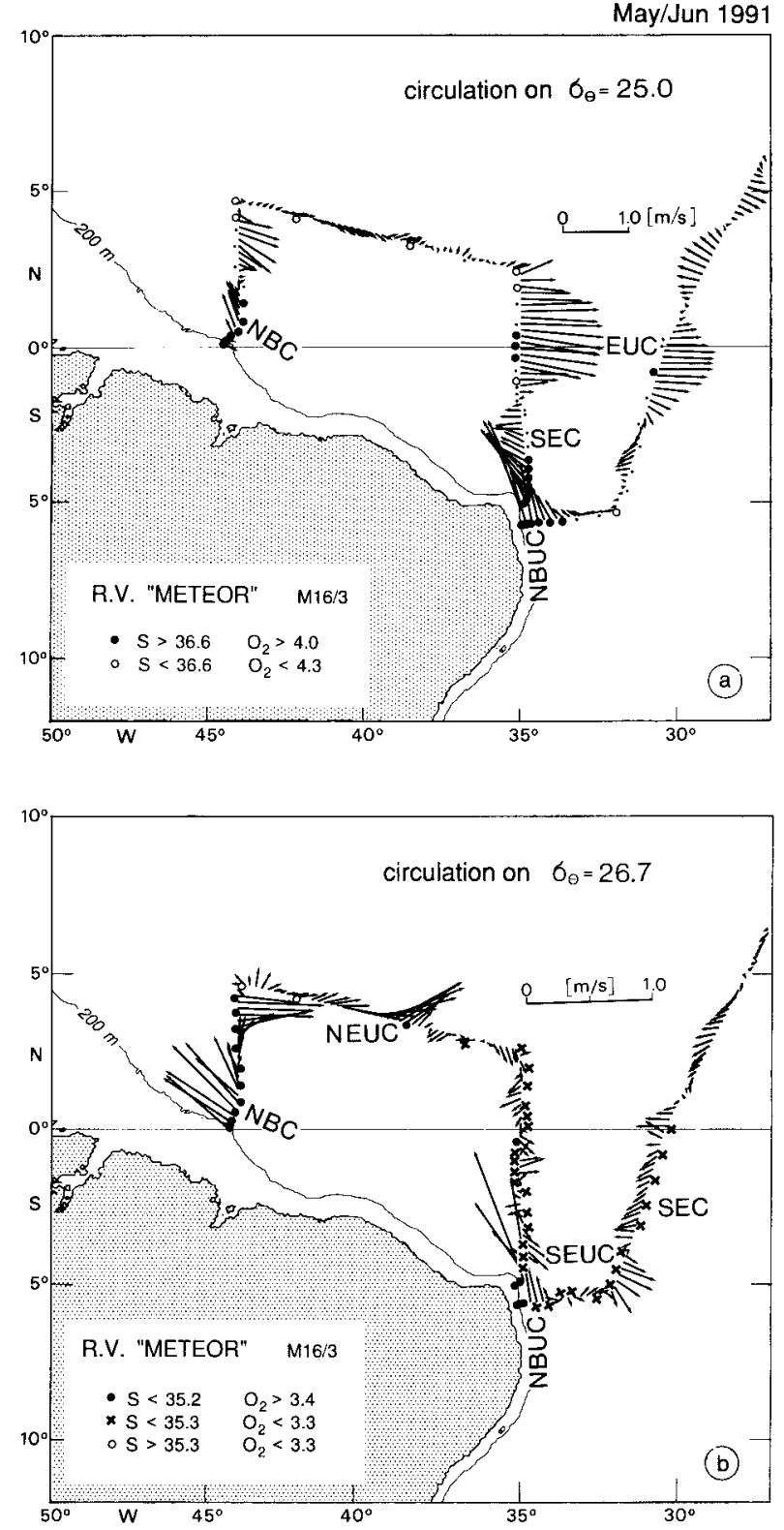

FIG. 6. Currents and water mass classes determined by $\mathrm{S}_{-} \mathrm{O}_{2}$ relations on $\sigma_{\Theta}$ surfaces (for details see legend and text; CTD stations that do not fall into the selected classes are marked by dots) during the May/June 1991 survey M16/3 for (a) $\sigma_{\Theta}=25.0$ and (b) $\sigma_{\Theta}=$ 26.7 .

The flow at $\sigma_{\Theta}=26.7$ shows strong eastward currents at $4^{\circ}-5^{\circ} \mathrm{N}$ across $44^{\circ} \mathrm{W}$ that seem to supply the North Equatorial Undercurrent in an eastward branch in the slant section at $38^{\circ}-39^{\circ} \mathrm{W}$. Two weeks later, however, when the Meteor crossed the equator again further east, heading northward at $30^{\circ} \mathrm{W}$, there was no eastward current core to be detected in the NEUC latitude range (Fig. 6b). The South Equatorial Undercurrent is visible in both the $35^{\circ} \mathrm{W}$ and the $31^{\circ} \mathrm{W}$ sections at $3^{\circ}-5^{\circ} \mathrm{S}$.

Identifying water masses as of southern origin for $S$
$<35.20 \mathrm{psu}, \mathrm{O}_{2}>3.4 \mathrm{ml} \mathrm{l}^{-1}$ shows a connection along the current core of the NEUC, suggesting partial supply of that subthermocline countercurrent from the south through the NBC retroflection that merges with the highsalinity lower-oxygen supply from the north. The SEUC current core, however, is again not marked by southern water out of the boundary current, but by low-oxygen interior recirculation.

\section{c. March-April 1996, M34/4}

This survey is unique compared to the other Meteor studies reported on here in that it covered various sections between $7^{\circ} \mathrm{S}$ and the inflow to the Caribbean (Fig. 1). Since this was a geological cruise with Paleoclimate objectives, the physical oceanography contribution was secondary in determining cruise tracks and only partial sections with minimum CTD coverage at reduced quality could be obtained. Near-surface currents are shown in Fig. $7 \mathrm{a}$, and the salinity-maximum water is marked at the $\sigma_{\Theta}=25.0$ level from the available CTD stations. Isopycnal depths for the boundary currents from the CTD stations of that cruise could be reasonably well determined except for the equatorial section (Fig. 7) where no casts were taken. For the boundary current across that section (Table 1) we used isopycnal depths from the prior cruises. The estimated error in layer transport is about $25 \%$ for that case. Salinities exceeding 36.6 psu occurred on all sections along the coast in March 1996. The current patterns and salinities suggest that this was a situation where a continuous flow band along the coast carried South Atlantic near-surface waters toward the Caribbean. Yet, as mentioned before, salinity does not allow a distinction between southern waters and those coming from out of the northern subtropics.

Currents at $\sigma_{\Theta}=26.7$ show a strong SEUC branch with currents of $30 \mathrm{~cm} \mathrm{~s}^{-1}$, and northwestward flow along the coast in all the boundary sections (Fig. 7b). Transports of the current core in the range above $\sigma_{\Theta}=$ 26.8 are marked in Fig. 7a. The transports support the existence of a throughflow from south of the equator to near the entrance of the Caribbean of about $12 \mathrm{~Sv}$, which is the same value as the throughflow estimated for March 1994 from the $44^{\circ} \mathrm{W}$ transport budget. In May 1996, the boundary current was measured again during the French ETAMBOT program, and a significant northwestward boundary current was also observed (B. Bourles 1997, personal communication).

At $9^{\circ}-12^{\circ} \mathrm{N}$ there appeared to be an anticyclonic eddy and how much of this boundary flow actually entered the Caribbean versus how much recirculated to the east remained unclear (Fig. 7a,b).

\section{Near-surface circulation in northern fall}

For fall, the expectation is that the cross-equatorial NBC flow is distributed through retroflections into the 
MAR 1996
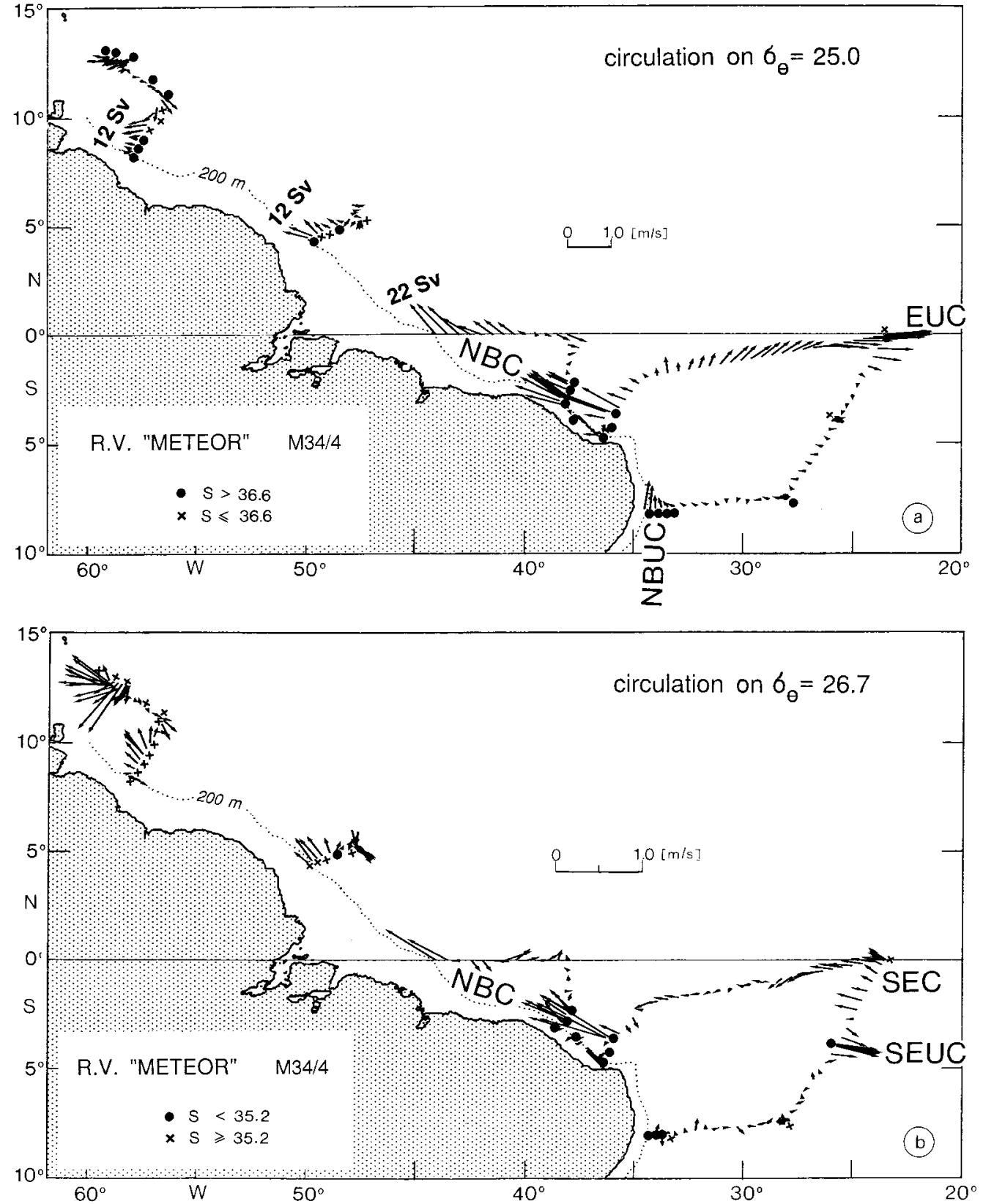

FIG. 7. Currents and salinity classes on $\sigma_{\Theta}$ surfaces (for details see text; CTD stations that do not fall into the selected classes are marked by crosses) during the March 1996 survey M34/4 for (a) $\sigma_{\Theta}=25.0$ and (b) $\sigma_{\Theta}=26.7$. Transports above $\sigma_{\Theta}=26.8$ are included in (a). Note that no salinity casts were taken on the equator.

NECC, the NEUC, and the EUC with no boundary flow of any significance continuing (e.g., Richardson and Philander 1987). Instead, the retroflection at times expands northward, then sheds a large anticyclonic eddy that drifts northwestward at $10-15 \mathrm{~cm} \mathrm{~s}^{-1}$, as demonstrated from satellite altimetry by Didden and Schott (1993) and from float tracks by Richardson et al. (1994).
Here we summarize the current patterns and water mass distributions from the investigations in October 1990 and October/November 1992.

It is interesting to note that in both fall surveys southern water mass characteristics are found only sporadically at the $44^{\circ} \mathrm{W}$ sections at $\sigma_{\Theta}=25.0$, different from the winter and spring surveys. However, the water mass- 
TABLE 1. Transports (in Sv) from shipboard current measurements at $44^{\circ} \mathrm{W}$.

\begin{tabular}{|c|c|c|c|c|c|c|}
\hline Isopycnal range & Aug $1989^{\text {e }}$ & Jun 1991 & Oct 1992 & Mar 1994 & Mar 1996 & Mean \\
\hline \multicolumn{7}{|c|}{ NBC transports across section (mainly westward) } \\
\hline $\begin{array}{l}<\sigma_{\Theta}=24.5 \\
\sigma_{\Theta}=24.5-26.8 \\
\sigma_{\Theta}=26.8-1000 \mathrm{~m} \\
\text { Total }\end{array}$ & $\begin{array}{c}-10.8 \\
-1.9 \\
\ldots \\
\ldots\end{array}$ & $\begin{array}{r}-4.8 \\
-12.8 \\
-4.4 \\
-22.0\end{array}$ & $\begin{array}{c}-13.4^{\mathrm{b}} \\
-7.9 \\
-18.7 \\
-40.0\end{array}$ & $\begin{array}{l}-13.3 \\
-11.1 \\
-12.1 \\
-36.5\end{array}$ & $\begin{array}{l}-11.9^{c} \\
-12.9^{c} \\
\quad \cdots \\
\quad \cdots\end{array}$ & $\begin{array}{l}-11.9^{\mathrm{d}}-10.8^{\mathrm{a}} \\
-10.5^{\mathrm{d}}-11.8^{\mathrm{a}} \\
-11.7^{\mathrm{d}}-12.2^{\mathrm{a}} \\
-34.1^{\mathrm{d}}-34.6^{\mathrm{a}}\end{array}$ \\
\hline \multicolumn{7}{|c|}{ Retroflection and NECC transports (eastward) } \\
\hline $\begin{array}{l}<\sigma_{\Theta}=24.5 \\
\sigma_{\Theta}=24.5-26.8 \\
\sigma_{\Theta}=26.8-1000 \mathrm{~m} \\
\text { Total }\end{array}$ & $\begin{array}{l}17.5 \\
22.1 \\
\cdots \\
\cdots\end{array}$ & $\begin{array}{r}7.1 \\
19.6 \\
12.3 \\
39.0\end{array}$ & $\begin{array}{l}19.5 \\
11.2 \\
17.0 \\
47.7\end{array}$ & $\begin{array}{r}4.5 \\
14.5 \\
28.7 \\
47.7\end{array}$ & $\begin{array}{l}\cdots \\
\cdots \\
\cdots \\
\cdots\end{array}$ & $\begin{array}{c}12.2 \\
16.8 \\
19.3 \\
\cdots\end{array}$ \\
\hline
\end{tabular}

${ }^{a}$ From a combination of all current meter records and shipboard data.

${ }^{\mathrm{b}}$ Northward to $2.0^{\circ} \mathrm{N}$.

${ }^{c}$ Coast to $40^{\circ} \mathrm{W}$ along the equator.

${ }^{\mathrm{d}}$ Averaged core transports from shipboard data.

${ }^{\mathrm{e}}$ From the section of Wilson et al. (1994).

es still relate the EUC at $35^{\circ} \mathrm{W}$ and the $5^{\circ}-10^{\circ} \mathrm{S}$ source area. Here $\Theta-S$ profiles show lower salinities in the nearsurface layer at $44^{\circ} \mathrm{W}$ for the two northern fall cruises. Also at $\sigma_{\Theta}=26.7$ the two northern fall cruises show lower salinities near the shelf, which in contrast to the upper-surface indicates a stronger northward extent of southern water, although this is not clearly reflected in variations of the layer transports of the NBC.

Salinities at $\sigma_{\Theta}=25.0$ (Fig. 8a) show the spreading of salinity-maximum water along the boundary near Cape San Roque with salinities $>36.6$ psu. The current vectors show the flow along the boundary at $35^{\circ} \mathrm{W}$ and off eastward into the undercurrent, but it mixes with the less saline northern equatorial water.

At $\sigma_{\Theta}=26.7$ the extent of southern water masses is limited to the region south of the equator, including the lower part of the SEUC, but reaches the equator at $44^{\circ} \mathrm{W}$ in the NBC.

In November 1992 the upper-layer currents show, besides an EUC at $35^{\circ} \mathrm{W}$ but with only a weak retroflection supply at $44^{\circ} \mathrm{W}$, an eastward current at $4^{\circ}-7^{\circ} \mathrm{N}$ (Fig. 9a), which decays toward the $\sigma_{\Theta}=26.7$ level (Fig. 9b). This is the southern end of the NECC, and the water mass properties at $44^{\circ} \mathrm{W}$ and $35^{\circ} \mathrm{W}$ (Fig. 9a) indicate a significant contribution of northern waters with lower salinity. At the $\sigma_{\Theta}=26.7$ level, an offshore countercurrent to the lower NBC is seen at $44^{\circ} \mathrm{W}$, which the $S-\mathrm{O}_{2}$ relations indicate to be a retroflection of southern water masses. The eastward core at $2^{\circ}-3^{\circ} \mathrm{S}$ along the $35^{\circ} \mathrm{W}$ section is the SEUC, which is imbedded in southern waters but has too low oxygen contents, however, to be associated with them.

\section{AAIW circulation}

As mentioned, the core of the Antarctic Intermediate Water in the western equatorial Atlantic is located at $\sigma_{\Theta}=27.28$. Oxygens of $\mathrm{O}_{2}>3.6 \mathrm{ml} \mathrm{l}^{-1}$ and salinities $<34.50$ psu mark the southern inflow region in the lower part of the NBUC at $5^{\circ} \mathrm{S}-10^{\circ} \mathrm{S}$ (Fig. 10).
The surveys show the $\mathrm{O}_{2}$-maximum and salinity-minimum water propagating along the Brazil coast around Cape San Roque, in agreement with the alongshore flow of the NBUC. Between $1^{\circ} \mathrm{N}$ and $1^{\circ} \mathrm{S}$ the Equatorial Intermediate Current (EIC) flows generally westward at that level, carrying waters of higher salinities and lower oxygens. In June 1991, though, the equatorial band showed eastward currents at $\sigma_{\Theta}=$ 27.28 (Fig. 10a); the reason was not that the EIC did not exist at that time but that it had a much smaller extent and transport than in the other surveys and did not reach up to that level. At $1^{\circ}-3^{\circ} \mathrm{S}$ the Southern Intermediate Countercurrent (SICC) carries waters of boundary current signatures eastward into the interior. Its northern counterpart, the NICC, cannot as clearly be connected to the boundary waters but one still detects secondary $\mathrm{O}_{2}$-maxima and salinity minima in its latitude range, indicating that the NICC is partially supplied by boundary current waters.

It was quite surprising to note that the coverage by waters of $\mathrm{O}_{2}>3.6 \mathrm{ml} \mathrm{l}^{-1}$ and $\mathrm{S}<34.50$ psu showed significant variability among the cruises. While in October 1992 the southern end of the $44^{\circ} \mathrm{W}$ section is occupied by these water properties and a connection along the NICC latitude can be seen, the June 1991 distributions shows a much sparser coverage by this water type. Although the LADCP currents (merged with some Pegasus profiles) are generally noisier than the upper-layer shipboard ADCP currents presented in previous figures, they show significant offshore recirculations, for example, at $10^{\circ} \mathrm{S}$ (Fig. 10c) and at $44^{\circ} \mathrm{W}$, suggesting difficulties in determining net transport of circulation branches in the subsequent chapters. Southward offshore flow at the AAIW core level was also observed by RAFOS floats at $5^{\circ}-10^{\circ} \mathrm{S}$ (W. Zenk 1997, personal communication), and it is also indicated in the 800-dbar map of Reid (1989) at that latitude range. 

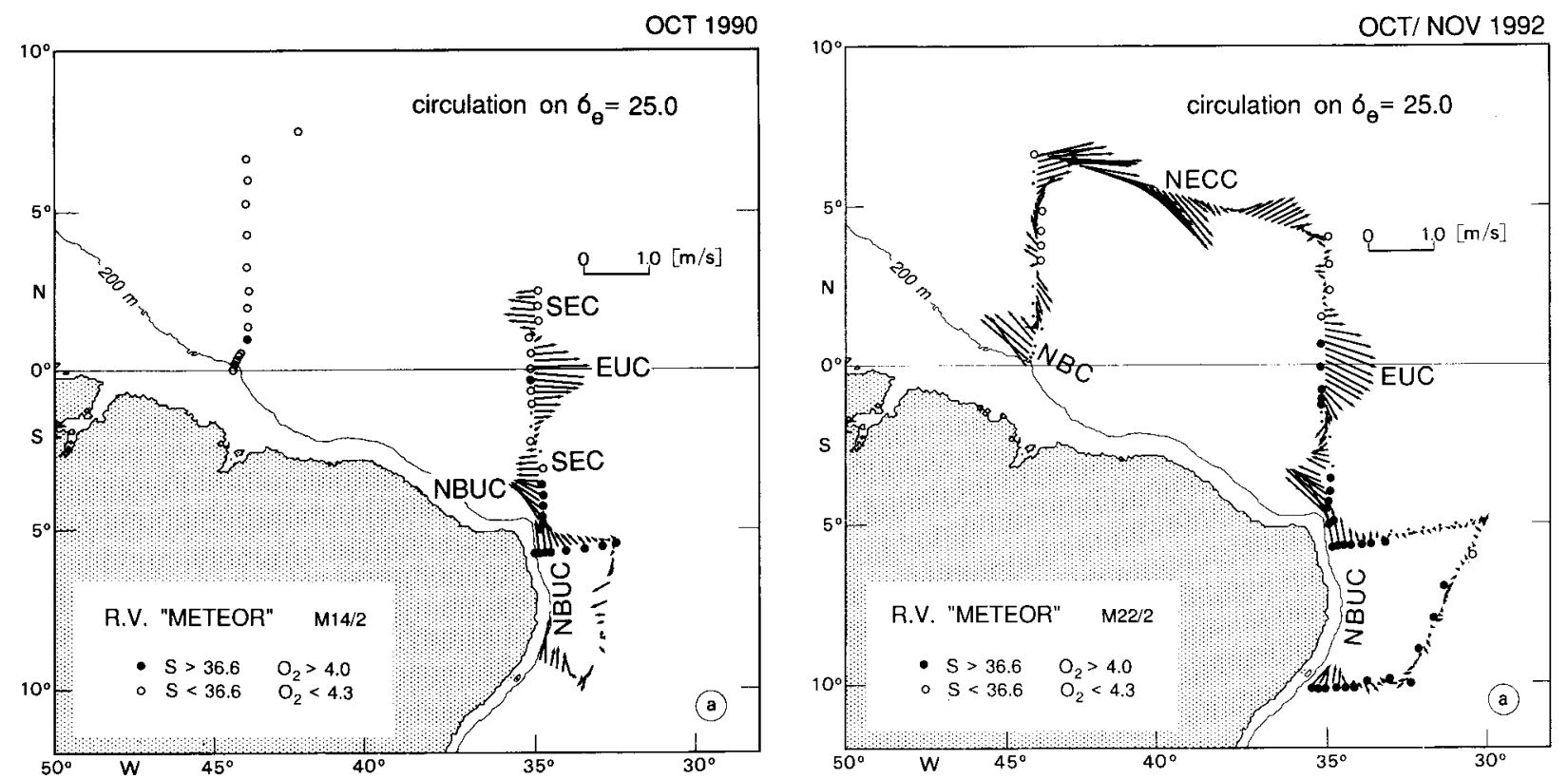

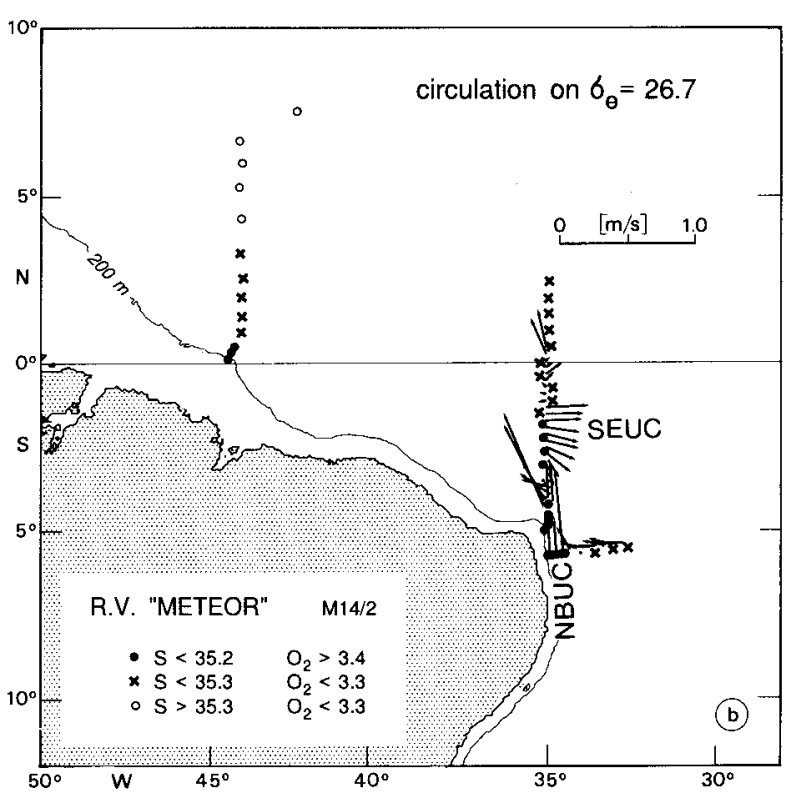

FIG. 8. Same as Fig. 6, but for R/V Meteor cruise M14/2 in October 1990. Due to restricted vertical range of shipboard ADCP data a combination of LADCP/Pegasus data is used.

\section{The North Brazil Current at the equator}

After the superposition of the NBUC and the SEC at $35^{\circ} \mathrm{W}$, north of Cape San Roque in the latitude range $3^{\circ}-5^{\circ} \mathrm{S}$, the North Brazil Current (NBC) passes along the western boundary as a surface-intensified western boundary current. Its mean transport in the upper 300 $\mathrm{m}$, when crossing the equator at $44^{\circ} \mathrm{W}$, was determined at $24 \mathrm{~Sv}$ by Schott et al. (1993) from three moored upward-looking ADCPs (at stations 339-341, Fig. 11). The annual cycle was estimated then at only about $10 \%$

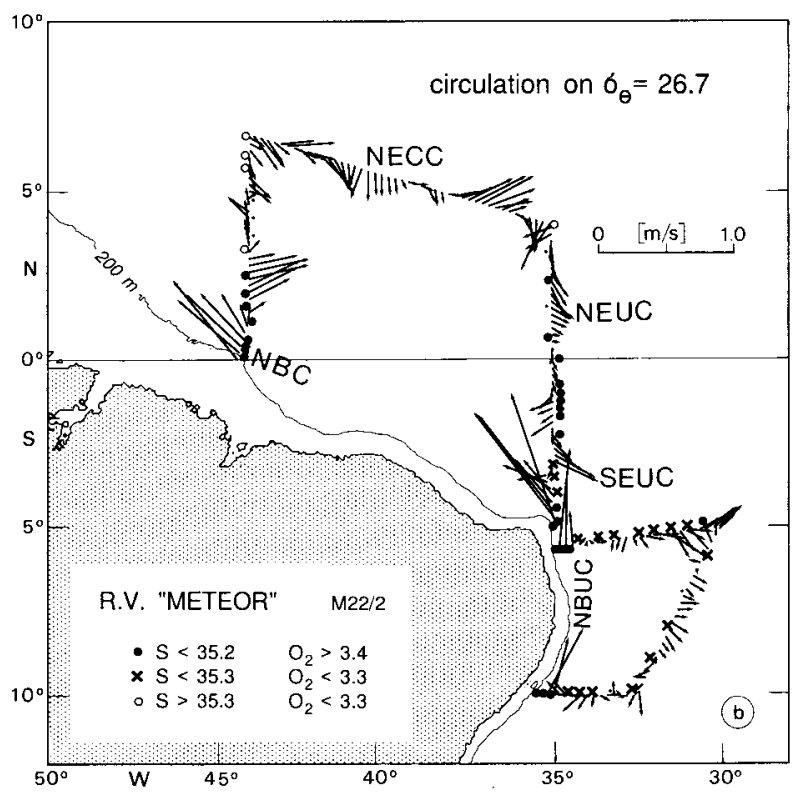

FIG. 9. Same as Fig. 6 but for the October/November 1992 survey $\mathrm{M} 22 / 2$.

of the mean, with maximum northwestward flow in June-August and its minimum in northern spring. However, vigorous intraseasonal fluctuations with periods of $1-2$ months and transport fluctuations of up to $\pm 8 \mathrm{~Sv}$ are superimposed on whatever small annual cycle there is.

Overall, three passes of the $44^{\circ} \mathrm{W}$ section with velocity profiling have been carried out by IfM Kiel (Table 1 and Figure 12), and the addition of the moored arrays made the NBC the best-covered current core in our study (see Fig. 1). A best estimate of the NBC at $44^{\circ} \mathrm{W}$ was 

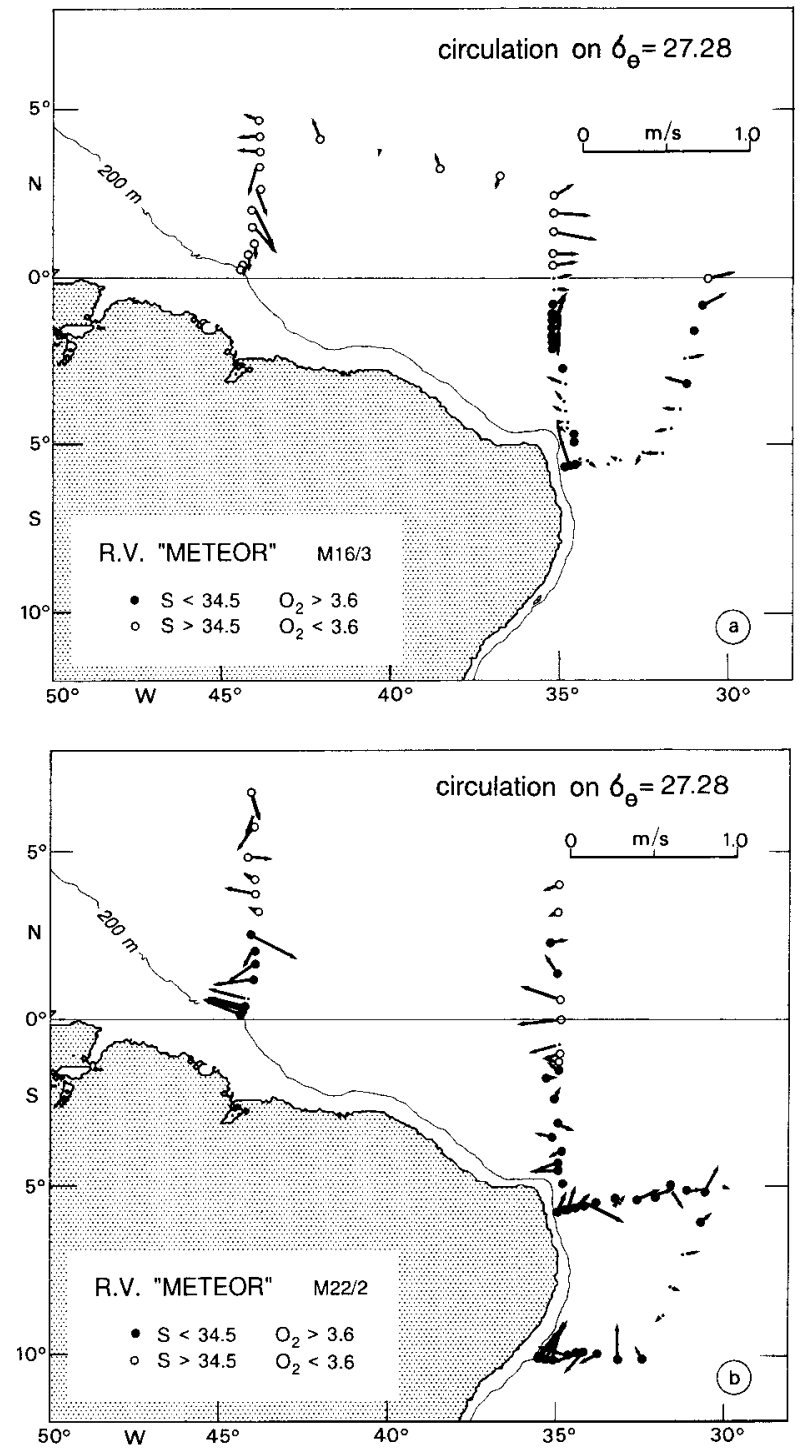

achieved by combining the available moored current records in the upper $1000 \mathrm{~m}$ with the shipboard current measurements from all cruises. The mapping scale used was $20-\mathrm{km}$ horizontal and $100-\mathrm{m}$ vertical. The shipboard sections were weighed into the mean as being equivalent to monthly moored current means. Thus, the result is dominated by the moored records where the instruments were densely spaced, and by shipboard measurements where the instrument coverage was sparse. The NBC (Fig. 11a) extends northward to about $1.8^{\circ} \mathrm{N}$ and downward to at least $1000 \mathrm{~m}$. Maximum currents at the shelf break are in excess of $1 \mathrm{~m} \mathrm{~s}^{-1}$, decaying rapidly downward with half of the current amplitude sheared away at the depth of $\sigma_{\Theta}=26.8$. A weak secondary northwestward current maximum is found near $800 \mathrm{~m}$ in the depth range of AAIW.

For the upper layer, $0-300 \mathrm{~m}$ (i.e., roughly above $\sigma_{\Theta}$ $=26.8)$, the transport determined here is the same as

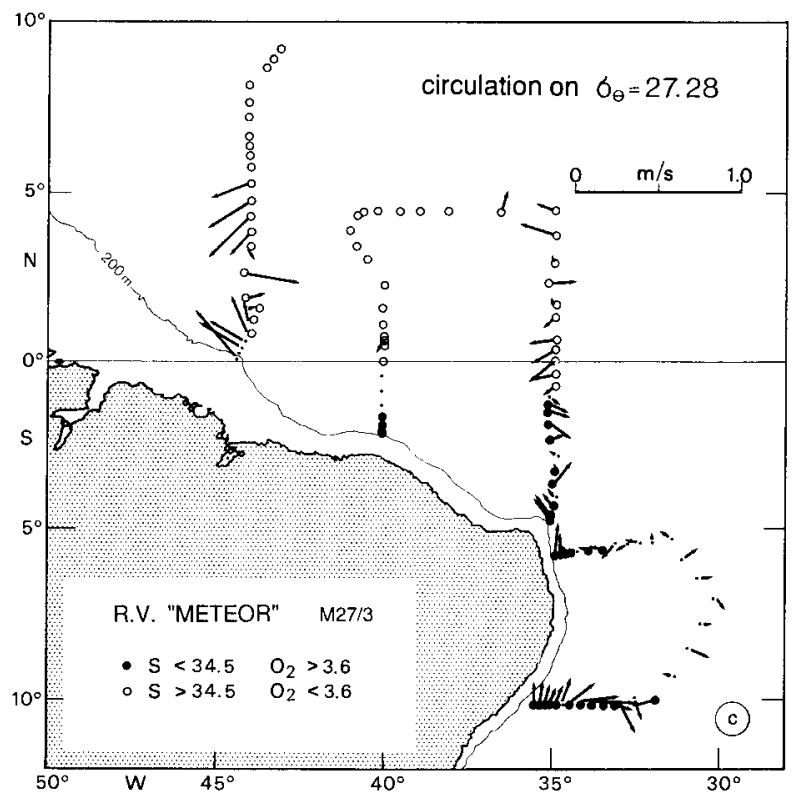

FIG. 10. Currents and water mass classes determined by $S-\mathrm{O}_{2}$ relations in the AAIW core on $\sigma_{\Theta}=27.28$ (a) in May/June 1991, M16/ 3; (b) in October/November 1992, M22/2 and; (c) in March 1994, M27/3.

in the analysis of Schott et al. (1993) within about $2 \mathrm{~Sv}$ (22.4 Sv compared to $23.8 \mathrm{~Sv}$, Table 2), and even in the layer 300-600 m, which was not well supported by the earlier observations, the agreement was reasonable [5.1 Sv this study compared to $6.7 \mathrm{~Sv}$ by Schott et al. (1993)]. It is the NBC transport in the AAIW layer of 600-1000 m, amounting to $6.4 \mathrm{~Sv}$, about which we are much more confident now than in the earlier study when we did not want to make a transport estimate for that layer from the sparse available data. Overall, we obtain now a mean NBC cross-equatorial transport of $34.6 \mathrm{~Sv}$ above $1000 \mathrm{~m}$.

The close correspondence between the values of Schott et al. (1993) obtained from a subset of the data with the mean NBC transport might be taken as an indication of low interannual variability. There is also good agreement of the total mean transport of $34.6 \mathrm{~Sv}$ (dominated by the moored current means) for the upper 

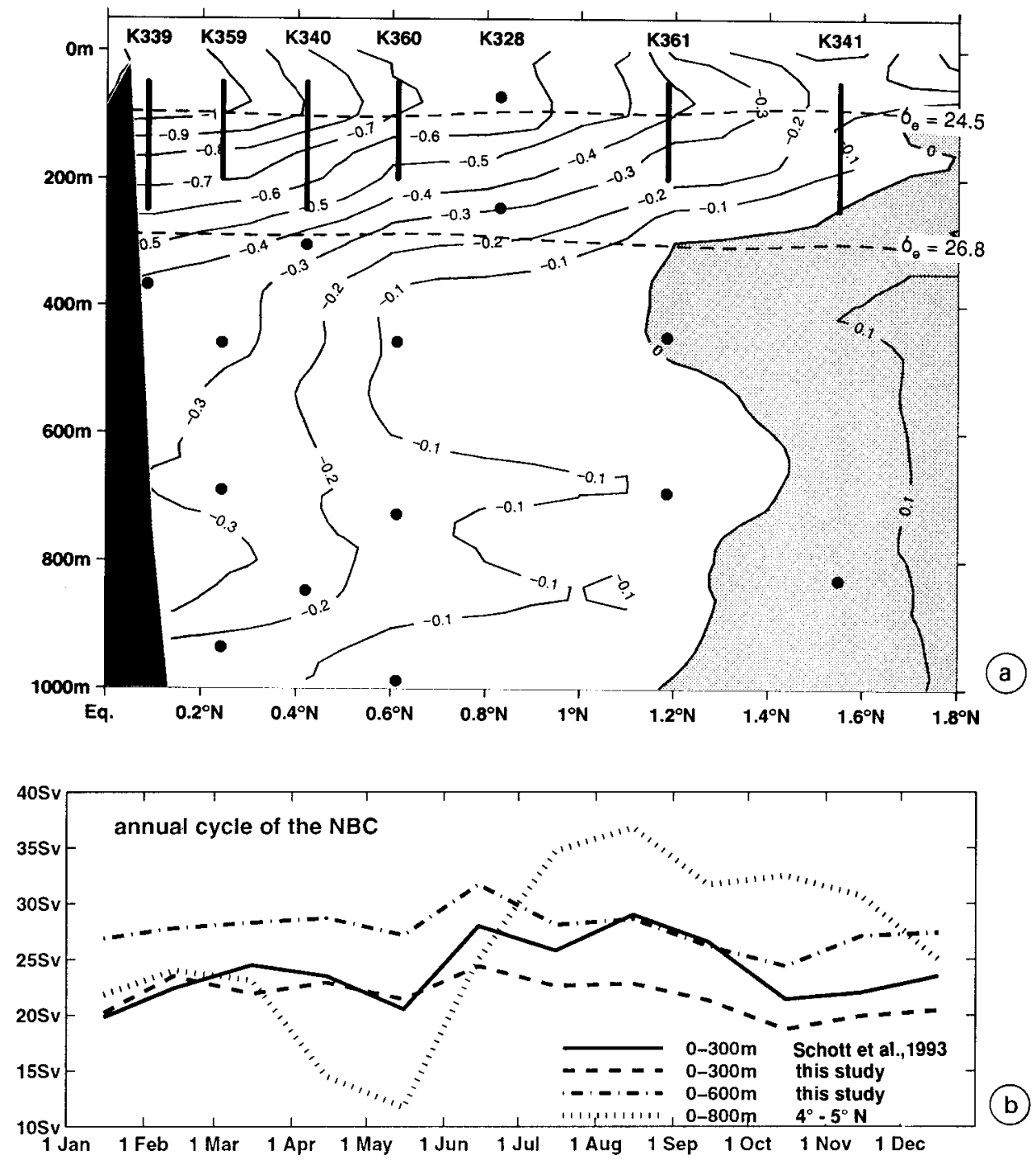

Fig. 11. (a) The North Brazil Current at $44^{\circ} \mathrm{W}$ (in $\mathrm{m} \mathrm{s}^{-1}$ ) from a combination of all current meter data in the upper $1000 \mathrm{~m}$ and all shipboard current measurements (the records from different deployment years were used as if they were from the same year). (b) Time series of monthly mean transports determined from current meter records alone; transports from $4^{\circ}$ to $5^{\circ} \mathrm{N}$ are from STACS array (Fig. 1 of Johns et al. 1998).

$1000 \mathrm{~m}$ with the mean of $34.1 \mathrm{~Sv}$ from the three ship sections (Table 1).

An annual cycle of NBC transports has been composed by calculating monthly means from all moored observations regardless of the year when they were taken (Fig. 11b). By applying monthly averaging the effect of the strong transport variations of about monthly period (Schott et al. 1993) is damped in the figure. While the earlier observations suggested a seasonal maximum of the transport in June-August in the layer 0-300 m, this maximum is reduced when the additional data from moorings 359-361 (dashed line in Fig. 11b) are included. What is reproduced in the complete dataset are the low transports in October. The transport range of monthly means is only $\pm 2.5 \mathrm{~Sv}$, about $10 \%$ of the mean.
For the layer 0-600 m, the transport varies from 31.7 $\mathrm{Sv}$ in June to $24.4 \mathrm{~Sv}$ in October.

An astonishing amplification of the seasonal transport cycle of the NBC occurs between our equatorial $44^{\circ} \mathrm{W}$ section and $4^{\circ}-5^{\circ} \mathrm{N}$, where Johns et al. (1998) determined transports from a moored array (Fig. 11b). They found a transport variation from a minimum of $13 \mathrm{~Sv}$ in April-May to a maximum of $36 \mathrm{~Sv}$ in July-August for the upper $800 \mathrm{~m}$. The difference between this large and the small equatorial cycle of the NBC is only partly due to a net boundary transport change, whereas dominantly it should be due to the seasonal migration of the retroflection zone, which has its maximum northwestward extension in boreal fall, when it begins spawning NBC eddies. 


\section{$44^{\circ} \mathrm{W}$}

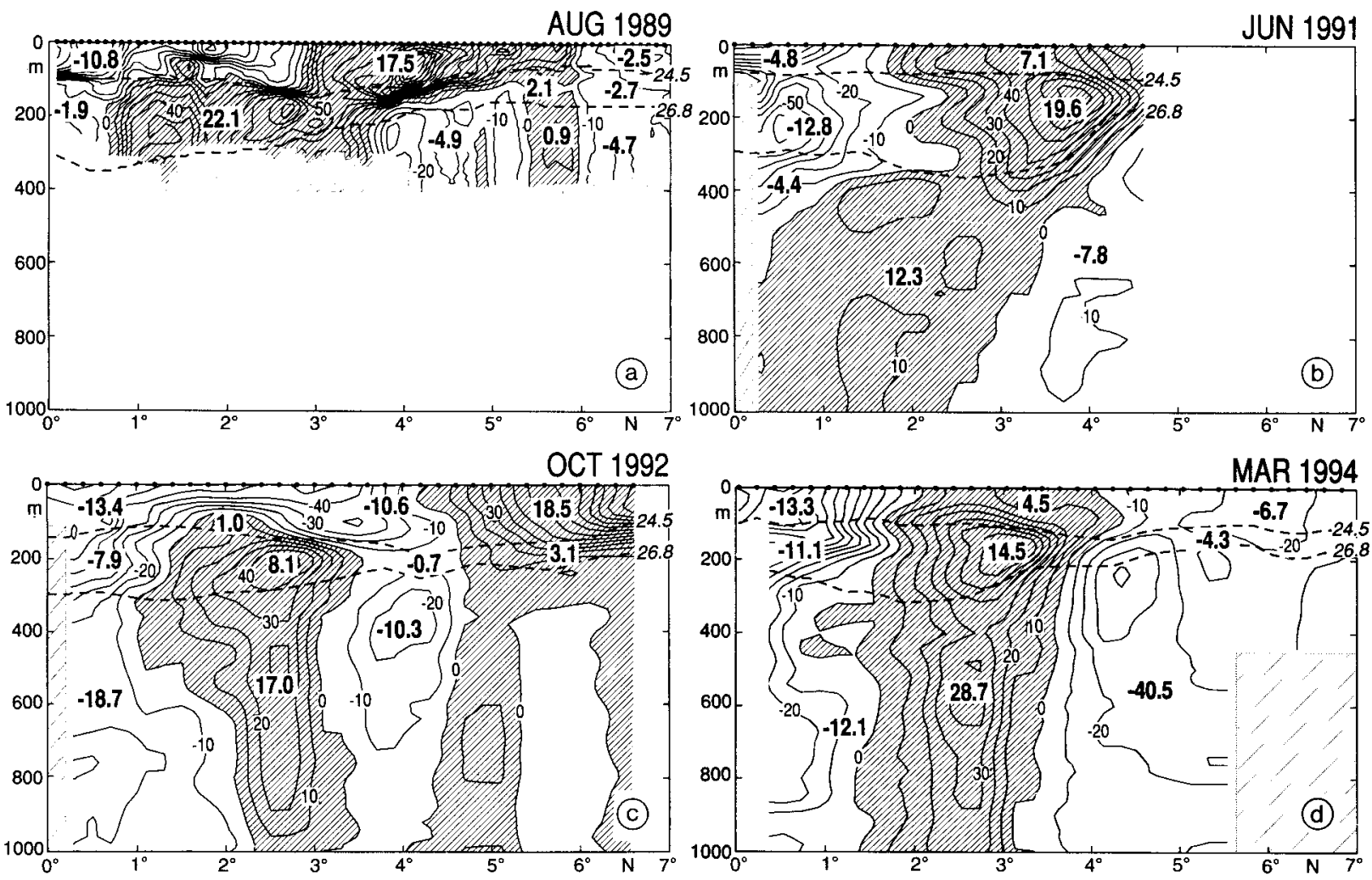

FIG. 12. Zonal currents at $44^{\circ} \mathrm{W}$ (in $\mathrm{cm} \mathrm{s}^{-1}$ ) for (a) August 1989 [from sections of Wilson et al. (1994)], (b) for June 1991 (M16/3), (c) for October 1994 (M22/2), and (d) for March 1992 (M27/3); transports across the sections and between isopycnals are marked, westward currents are shaded.

\section{Currents and transports of circulation branches}

\section{a. South equatorial circulation}

\section{1) The North BraziL UndercurRent}

As regards the boundary circulation south of the equator, a new discovery of the Meteor current profiling sections along $5^{\circ} \mathrm{S}$ and $10^{\circ} \mathrm{S}$ was the existence of an equatorward undercurrent, the North Brazil Undercurrent (NBUC) (Stramma et al. 1995; Schott et al. 1995). At $10^{\circ} \mathrm{S}$, its velocity maximum is located at about 250 $m$ depth (Figs. 13e,f), and at 600-m depth velocities still exceed $20 \mathrm{~cm} \mathrm{~s}^{-1}$. At $5^{\circ} \mathrm{S}$, the current core has risen to
150-200 m (Figs. 13a-d). The core is encompassed by the $\sigma_{\Theta}=24.5$ and 26.8 isopycnals, but a large transport fraction is carried in the layer between $\sigma_{\Theta}=26.8$ and $1000 \mathrm{~m}$. As mentioned, this undercurrent was first found in the CME model circulation (Schott and Böning 1991), and subsurface velocity cores off Northeast Brazil were indicated in a sketch of the equatorial circulation by Gouriou and Reverdin (1992, their Fig. 18). For the March 1983 R/V Oceanus section along $11^{\circ} 15^{\prime} \mathrm{S}$, Reverdin et al. (1993) described a near-coastal northward flow of $17 \mathrm{~Sv}$, located underneath a weak southward surface flow.

TABLE 2. NBC transports from current meter records $\left(\mathrm{Sv} \equiv 10^{6} \mathrm{~m}^{3} \mathrm{~s}^{-1}\right)$.

\begin{tabular}{|c|c|c|c|c|c|c|}
\hline \multirow{2}{*}{$\begin{array}{l}\text { Depth range } \\
(\mathrm{m})\end{array}$} & \multicolumn{3}{|c|}{ Schott et al. (1993) } & \multicolumn{3}{|c|}{ This study } \\
\hline & Mean & Dec-Feb & Jun-Aug & Mean & Dec-Feb & Jun-Aug \\
\hline $0-100$ & $-10.9^{\mathrm{b}}$ & $-10.2^{\mathrm{b}}$ & $-13.9^{b}$ & $-10.8^{\mathrm{a}}$ & $-9.7^{b}$ & $-11.0^{\mathrm{b}}$ \\
\hline $100-300$ & $-12.9^{b}$ & $-11.8^{\mathrm{b}}$ & $-13.9^{b}$ & $-12.3^{\mathrm{a}}$ & $-11.7^{b}$ & $-12.3^{\mathrm{b}}$ \\
\hline $300-600$ & $(-6.7)^{b}$ & $\ldots$ & $\ldots$ & $-5.1^{\mathrm{a}}$ & $-5.8^{\mathrm{b}}$ & $-6.1^{\mathrm{b}}$ \\
\hline $600-1000$ & $\ldots$ & $\ldots$ & $\ldots$ & $-6.4^{\mathrm{a}}$ & $\ldots$ & $\ldots$ \\
\hline $0-1000$ & $\ldots$ & $\ldots$ & $\ldots$ & $-34.6^{\mathrm{a}}$ & $\ldots$ & $\ldots$ \\
\hline
\end{tabular}

${ }^{\text {a }}$ From a combination of all current meter records and shipboard data.

${ }^{\mathrm{b}}$ From current meter records only. 

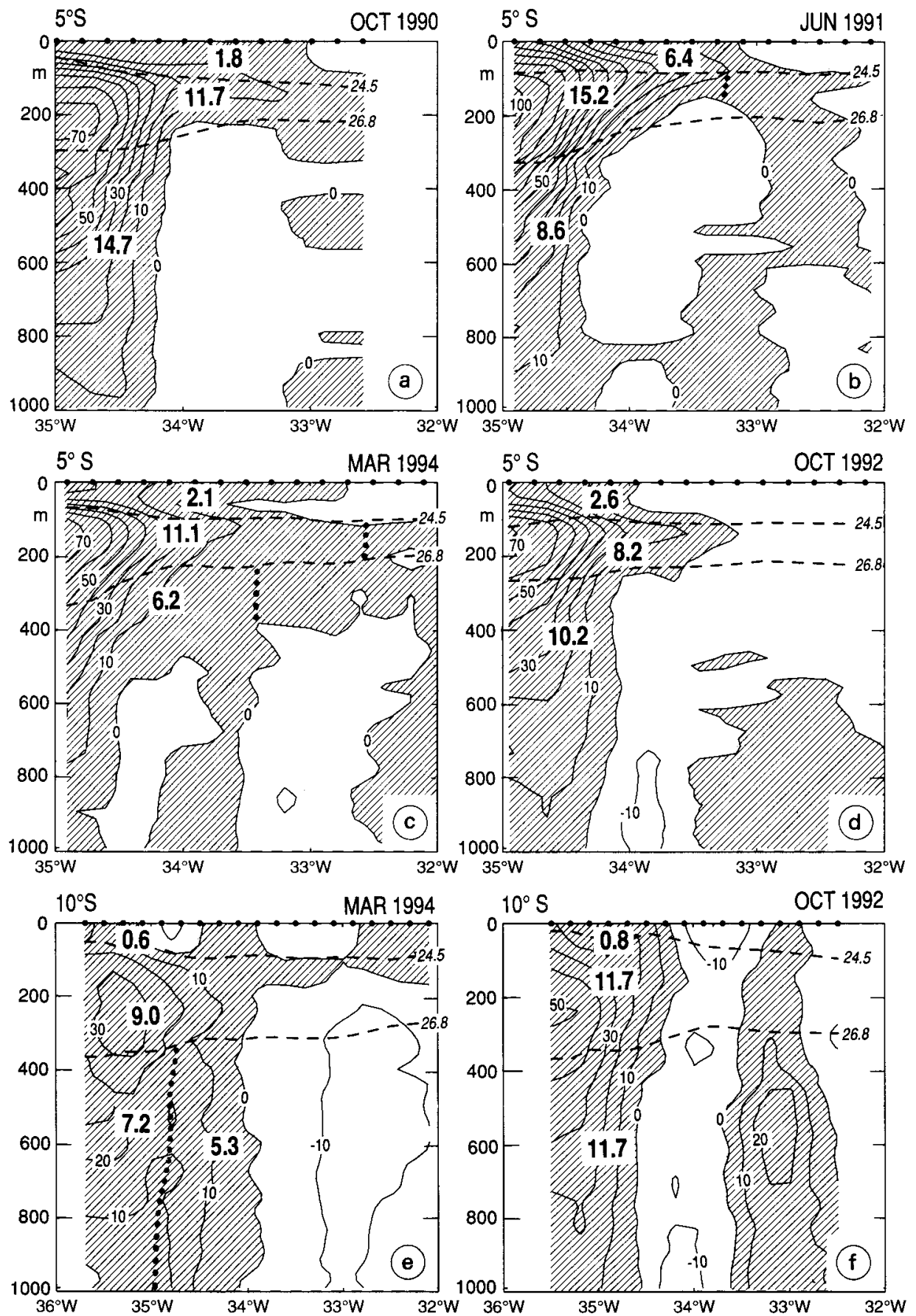

FIG. 13. Meridional currents in the latitude belt $5^{\circ} \mathrm{S}$ to $10^{\circ} \mathrm{S}$ from four cruises; northward currents are shaded; section locations and transports (Sv) between isopycnals are marked.

The $10^{\circ} \mathrm{S}$ section was measured three times by the Meteor: in October 1990 (only shipboard ADCP and XBTs), in November 92, and in March 94 (Table 3). The $10^{\circ} \mathrm{S}$ coverage with closely spaced stations during fall 1992 yielded a total NBUC transport of $24.2 \mathrm{~Sv}$ down to $1000 \mathrm{~m}$, based on LADCP profiling; and at $5^{\circ} \mathrm{S}, 21.0 \mathrm{~Sv}$, respectively, were passing northward in the current core directly adjacent to the coast. In March 1994 , the total transports were $22.1 \mathrm{~Sv}$ at $10^{\circ} \mathrm{S}$ and 19.4 $\mathrm{Sv}$ at $5^{\circ} \mathrm{S}$, respectively.

While at $5^{\circ} \mathrm{S}$ the transports offshore from the nearcoastal cores are small in both surveys (Fig. 13c,d), there is substantial offshore recirculation below $\sigma_{\Theta}=$ 26.8 at $10^{\circ} \mathrm{S}$ in those direct current measurements. This 
TABLE 3. Transports of the North Brazil Undercurrent (in Sv) at $5^{\circ} \mathrm{S}$ and $10^{\circ} \mathrm{S}$; positive cross-section transports northward. Values in parentheses are for geostrophic transports relative to $\sigma_{1}=32.15$.

\begin{tabular}{|c|c|c|c|c|c|c|c|}
\hline Isopycnal range & Oct 1990 & Jun 1991 & Nov 1992 & Mar 1994 & Mar $1996-7^{\circ} \mathrm{S}$ & Mean & Std. dev. \\
\hline \multicolumn{8}{|c|}{$5^{\circ} \mathrm{S}$ section } \\
\hline$<\sigma_{\Theta}=24.5$ & 1.8 & 6.4 & 2.6 & 2.1 & 3.8 & 3.2 & 1.7 \\
\hline$\sigma_{\Theta}=24.5-26.8$ & 11.7 & 15.2 & 8.2 & 11.1 & 10.9 & 11.4 & 2.5 \\
\hline$\sigma_{\Theta}=26.8-1000 \mathrm{~m}$ & 14.7 & 8.6 & 10.2 & 6.2 & $\ldots$ & 10.0 & 3.5 \\
\hline Total & 28.2 & 30.2 & 21.0 & 19.4 & $\cdots$ & 24.7 & 5.1 \\
\hline \multicolumn{8}{|c|}{$10^{\circ} \mathrm{S}$ section } \\
\hline$<\sigma_{\Theta}=24.5$ & $\cdots$ & $\cdots$ & $0.8(1.0)$ & $0.6(0.7)$ & $\cdots$ & 0.7 & $\cdots$ \\
\hline$\sigma_{\Theta}=24.5-26.8$ & $\cdots$ & $\ldots$ & $11.7(13.4)$ & $9.0(11.4)$ & $\ldots$ & 10.4 & $\ldots$ \\
\hline$\sigma_{\Theta}=26.8-1000 \mathrm{~m}$ & $\ldots$ & $\ldots$ & $11.7(10.9)$ & $12.5(11.5)$ & $\ldots$ & 12.1 & $\ldots$ \\
\hline Total & $\cdots$ & $\cdots$ & $24.2(25.2)$ & $22.1(23.6)$ & $\cdots$ & 23.3 & $\cdots$ \\
\hline \multicolumn{8}{|c|}{$10^{\circ} \mathrm{S}$ section by temperature classes } \\
\hline$>24^{\circ} \mathrm{C}$ & $\ldots$ & $\ldots$ & 2.6 & 2.0 & $\ldots$ & 2.3 & $\ldots$ \\
\hline $17^{\circ}-24^{\circ} \mathrm{C}$ & $\ldots$ & $\ldots$ & 4.2 & 2.7 & $\ldots$ & 3.5 & $\ldots$ \\
\hline $12^{\circ}-17^{\circ} \mathrm{C}$ & $\ldots$ & $\ldots$ & 3.8 & 4.3 & $\ldots$ & 4.1 & $\ldots$ \\
\hline $7^{\circ}-12^{\circ} \mathrm{C}$ & $\ldots$ & $\ldots$ & 5.5 & 5.0 & $\ldots$ & 5.3 & $\ldots$ \\
\hline $4^{\circ}-7^{\circ} \mathrm{C}$ & $\ldots$ & $\ldots$ & 6.4 & 6.6 & $\ldots$ & 6.5 & $\ldots$ \\
\hline
\end{tabular}

recirculation amounted to $13 \mathrm{~Sv}$ southward in 1994, and in 1992 two alternating cores outside the coastal boundary current (Fig. 13f) yielded a combined net of about $5 \mathrm{~Sv}$ northward. The near-coastal core of 1994 at $10^{\circ} \mathrm{S}$ is much wider than in 1992, and the transport of $6.2 \mathrm{~Sv}$ given in Schott et al. (1995) for the layer $\sigma_{\Theta}=26.8$ $1000 \mathrm{~m}$ was for the inner core only. Taking the transport totals at $10^{\circ} \mathrm{S}$ out to the section limits at $32^{\circ} \mathrm{W}$ would thus yield big differences among the two surveys: a total of $27.4 \mathrm{~Sv}$ above $1000 \mathrm{~m}$ in 1992 versus only $7.7 \mathrm{~Sv}$ in 1994.

For comparison, we also show in Table 3 the geostrophic transports, calculated relative to the isopycnal $\sigma_{1}=32.15$, which Stramma et al. (1995) found to be a useful separation level above the NADW at $5^{\circ}-16^{\circ} \mathrm{S}$. These geostrophic transports show less offshore recirculation and they yield rather similar totals as our boundary core integration from the direct measurements, namely, 25.5 Sv above $1000 \mathrm{~m}$ for November 1992 (to be compared with 24.2 Sv directly measured) and 23.6 Sv for March 1994 (to be compared with 22.1 Sv directly measured).

In October 1990, the transport at $5^{\circ} \mathrm{S}$, determined from shipboard- and lowered ADCP and Pegasus with somewhat reduced horizontal resolution, was $28.2 \mathrm{~Sv}$ above $1000 \mathrm{~m}$, and in 1991, the merged profiling product yielded a total of $30.2 \mathrm{~Sv}$.

The means for the isopycnal layers, including the March 1996 data from $7^{\circ} \mathrm{S}$ with good CTD coverage, show a mean of $11.4 \pm 2.5 \mathrm{~Sv}$ in the undercurrent layer at $5^{\circ} \mathrm{S}$ - that is, only an inflow of $1 \mathrm{~Sv}$ from the east between $10^{\circ} \mathrm{S}$ and $5^{\circ} \mathrm{S}$ (Table 3). In the surface layer, above $\sigma_{\Theta}=24.5$, the northward boundary current at $5^{\circ} \mathrm{S}$ is $3.2 \pm 1.7 \mathrm{~Sv}$, up from $0.7 \mathrm{~Sv}$ at $10^{\circ} \mathrm{S}$-that is, with a significant SEC inflow contribution from the east.

For the AAIW layer, $\sigma_{\Theta}=26.8-1000 \mathrm{~m}$, the net transport across $5^{\circ} \mathrm{S}$ is $10.0 \pm 3.5 \mathrm{~Sv}$. The mean northward boundary current transport at $5^{\circ} \mathrm{S}$ of the four sec- tions is $24.7 \mathrm{~Sv}$, quite similar to the $10^{\circ} \mathrm{S}$ mean total above $1000 \mathrm{~m}$ of $23.3 \mathrm{~Sv}$ (Table 3 ). This transport provides a large supply for the cross-equatorial boundary current.

Overall, we can thus conclude from these measurements with good resolution that the source of this large boundary transport is located south of $10^{\circ} \mathrm{S}$ and there is almost no net inflow from the east between $5^{\circ}$ and $10^{\circ} \mathrm{S}$ in the upper $1000 \mathrm{~m}$.

For comparison with the transports given by other authors (e.g., Schmitz and Richardson 1991; Schmitz and McCartney 1993) for layers in-between temperature surfaces, such classification is also done in Table 3 . We will come back to this later.

\section{2) The South Equatorial Current, south of THE EQUATOR}

The SEC flow across $35^{\circ} \mathrm{W}$ is apparent from the four $35^{\circ} \mathrm{W}$ sections (Fig. 14). The SEC water masses below the mixed layer are generally lower in oxygen (Fig. 4b) and they are of lower salinity at the top but show higher salinity in the salinity maximum water in the NBUC boundary water masses (Fig. 4a).

Near the southern boundary, between $4^{\circ}$ and $5^{\circ} \mathrm{S}$, the current structure changes because the SEC overlies the NBUC that shoots past Cape San Roque (Fig. 14). The superposition of the surface-intensified SEC and the NBUC now causes a northwestward boundary current that has lost part of its subsurface character. Along the north Brazil coast, a clear distinction between the westward flowing NBC and SEC is no longer possible in the near-surface layer.

The mean transport above $\sigma_{\Theta}=26.8$ was $27.8 \mathrm{~Sv}$ (Table 4), the difference beween this transport and the NBUC inflow across $5^{\circ} \mathrm{S}$ of $14.6 \mathrm{~Sv}$ is the net SEC inflow from the east above $\sigma_{\Theta}=26.8$, that is, $13.2 \mathrm{~Sv}$.

In the layer $\sigma_{\Theta}=26.8-1000 \mathrm{~m}$ there is a reasonable 


\section{$35^{\circ} \mathrm{W}$}
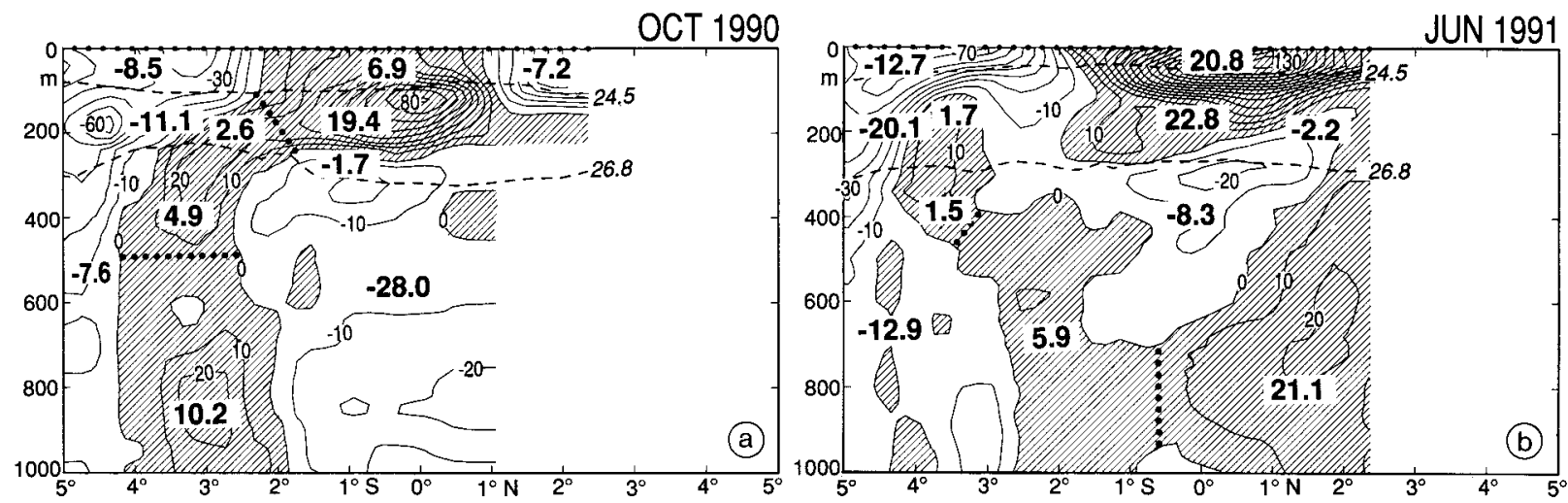

OCT 1992
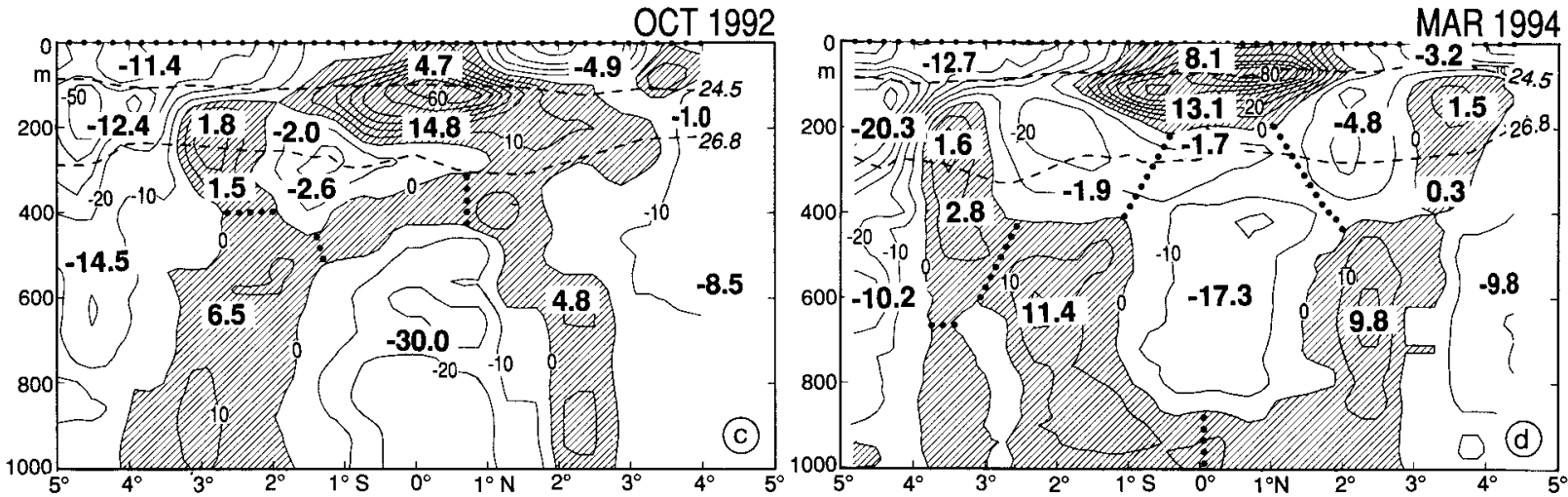

Fig. 14. Zonal currents at $35^{\circ} \mathrm{W}$ for (a) October 1990 (M14/2), (b) June 1991 (M16/3), (c) October 1992 (M22/2), and (d) for March 1994 (M27/3). Current cores are identified and their transports between isopycnals are marked.

correspondence between the $5^{\circ} \mathrm{S}$ section where a mean of 10.0 Sv passes northward and the transport of 12.4 $\mathrm{Sv}$ that continues westward across $35^{\circ} \mathrm{W}$, which means no significant supply for the deeper NBC from the east in latitude range $2^{\circ}-5^{\circ} \mathrm{S}$.

\section{3) The South Equatorial Undercurrent}

This current can be seen in the deep ADCP maps along $35^{\circ} \mathrm{W}$ of all four Meteor cruises (e.g., Figs. 6b, $9 b$, Fig. 14) with maximum speeds of $20-30 \mathrm{~cm} \mathrm{~s}^{-1}$ at

TABlE 4. Transports (in Sv) of the South Equatorial Current (SEC) including the NBUC, of the South Equatorial Undercurrent, and of the Equatorial Undercurrent at $35^{\circ} \mathrm{W}$ (positive is eastward).

\begin{tabular}{|c|c|c|c|c|c|c|c|}
\hline Isopycnal range & Oct 1990 & Jun 1991 & Nov 1992 & Mar 1994 & Mar $1996-26^{\circ} \mathrm{W}$ & Mean & Std. dev \\
\hline \multicolumn{8}{|c|}{$\mathrm{SEC}+\mathrm{NBUC}$, equator to $5^{\circ} \mathrm{S}$} \\
\hline$<\sigma_{\Theta}=24.5$ & -8.5 & -12.7 & -11.4 & -12.7 & & -11.3 & 2.0 \\
\hline$\sigma_{\Theta}=24.5-26.8$ & -11.1 & -20.1 & -14.4 & -20.3 & & -16.5 & 4.5 \\
\hline$\sigma_{\Theta}=26.8-1000 \mathrm{~m}$ & -7.6 & -12.9 & -17.1 & -12.1 & & -12.4 & 3.9 \\
\hline Total & -27.2 & -45.7 & -42.9 & -45.1 & & $-40.2\left(-35.2^{\mathrm{a}}\right)$ & 8.8 \\
\hline \multicolumn{8}{|c|}{ The Equatorial Undercurrent } \\
\hline$<\sigma_{\Theta}=24.5$ & 6.9 & 20.8 & 4.7 & 8.1 & & $6.6^{\mathrm{b}}$ & $1.7^{\mathrm{b}}$ \\
\hline$\sigma_{\Theta}=24.5-26.8$ & 19.4 & 22.8 & 14.8 & 13.1 & & 17.5 & 4.4 \\
\hline Total & 26.3 & 43.6 & 19.5 & 21.2 & & $22.3^{\mathrm{b}}\left(22.4^{\mathrm{a}}\right)$ & $3.5^{\mathrm{b}}$ \\
\hline \multicolumn{8}{|c|}{ The South Equatorial Undercurrent } \\
\hline$\sigma_{\Theta}=24.5-26.8$ & 2.6 & 1.7 & 1.8 & 1.6 & 11.4 & 1.9 & 0.5 \\
\hline$\sigma_{\Theta}=26.8-1000 \mathrm{~m}$ & 4.9 & 1.5 & 1.5 & 2.8 & 6.0 & 2.6 & 1.7 \\
\hline Total & 7.5 & 3.2 & 3.3 & 4.4 & 17.4 & $4.6\left(1.9^{\mathrm{a}}\right)$ & 2.1 \\
\hline
\end{tabular}

${ }^{a}$ From composite flow field.

${ }^{\mathrm{b}}$ Without June 1991.

(mean SEUC without March 1996) 
about 200-250-m depth. It is bounded at the top by the $\sigma_{\Theta}=26.30$ isopycnal and reaches down to $500 \mathrm{~m}-$ that is, below the depth range of the Meteor shipboard ADCP. Its total transport was calculated from the joint shipboard ADCP, lowered ADCP, and Pegasus data. The depth and axis location of the SEUC varied somewhat in our observations, and the separation from the EUC and Southern Intermediate Current was not always straightforward (e.g., in October 1990).

The SEUC carried a transport of $3.2 \mathrm{~Sv}$ across $35^{\circ} \mathrm{W}$ in June 1991 (Fig. 14b), increasing to $4.5 \mathrm{~Sv}$ when having reached $31^{\circ} \mathrm{W}$. In fall 1992, the transport across $35^{\circ} \mathrm{W}$ (Fig. $14 \mathrm{c}$ ) amounted to $3.3 \mathrm{~Sv}\left(1.8 \mathrm{~Sv}\right.$ above $\sigma_{\Theta}$ $=26.8)$, and the SEUC was also present in the eastern part of the slanted $5^{\circ} \mathrm{S}$ section (Fig. 9b) of that survey with the fractional transport covered in that section amounting to $3.5 \mathrm{~Sv}$. The total in March 1994 was 4.4 $\mathrm{Sv}$ with $2.8 \mathrm{~Sv}$ below $\sigma_{\Theta}=26.8$. A larger amount, 7.5 Sv, was determined for October 1990, however with no clear separation of the SEUC core (Fig. 14a). The overall mean at $35^{\circ} \mathrm{W}$ was determined to be $4.6 \pm 2.1 \mathrm{~Sv}$.

As pointed out already in the water mass discussion on $\sigma_{\Theta}=26.7$, the SEUC core at $35^{\circ} \mathrm{W}$ is not characterized by an oxygen maximum as associated with the NBUC and the SEUC stations for all four Meteor surveys do not match the NBUC source water mass characteristics. Rather, it has the low-oxygen properties of near-equatorial water from the east.

We have one section from farther east, taken at $25^{\circ}-$ $28^{\circ} \mathrm{W}$ during the March $1996 \mathrm{M} 34 / 4$ survey. In that section (Fig. 7b) the total eastward SEUC transport at $3^{\circ}-5^{\circ} \mathrm{S}$ was $17.4 \mathrm{~Sv}$, of which $6.0 \mathrm{~Sv}$ were carried below $\sigma_{\Theta}=26.8$ (Table 4). This eastward increase of the SEUC between $35^{\circ} \mathrm{W}$ and $26^{\circ} \mathrm{W}$ and the earlier findings of Molinari (1982) of significantly larger geostrophic SEUC currents in the longitude range $25^{\circ}-28^{\circ} \mathrm{W}$ supports that the SEUC is supplied by interior recirculation of near-equatorial SEC waters.

On the other hand, the evaluation of isotherm slopes from historical data by Molinari and Johns (1994) shows a turning of depth contours for the $10^{\circ} \mathrm{C}$ surface out of the NBUC into the SEUC. Tsuchiya (1986) described an oxygen maximum along the SEUC to the east of $35^{\circ} \mathrm{W}$. Our diagonal section at about $32^{\circ} \mathrm{W}$ in June 1991 showed a layer of oxygen maximum above a layer of oxygen minimum in the SEUC core. Therefore, the SEUC in the immediate source region at $35^{\circ} \mathrm{W}$ is made up of oxygen-poor water-that is, not supplied out of the NBUC retroflection, but on its way east the SEUC appears to entrain more oxygen-rich water.

\section{4) The South Equatorial Countercurrent}

An eastward-flowing countercurrent in the tropical South Atlantic, first mentioned by Reid (1964), exists in the latitudinal belt $7^{\circ}-9^{\circ} \mathrm{S}$. Eastward flow in the western tropical Atlantic had also been detected by Molinari (1982) in the latitude range $8^{\circ}-10^{\circ} \mathrm{S}$ in hydrographic section data. At $30^{\circ} \mathrm{W}$, which was roughly the eastward limit of the Meteor surveys in that latitude range, this current is apparently just beginning to form; it was quite weak, at typically $10 \mathrm{~cm} \mathrm{~s}^{-1}$ or less, in October 1990 and November 1992 (Fig. 9b) and showed westward velocities in spring 1994. It is not clear yet how this current is supplied in the west; its salinities suggest a more southern source than $10^{\circ} \mathrm{S}$. Transports were marginal and are not listed in the tables. The conclusion here is that the SECC is a rather weak element of the zonal circulation, at least in the western region.

\section{5) Seasonality south of THE EQUATOR}

Our measurements are too few to comment on a seasonal cycle of the upper-layer western boundary current south of the equator. At $5^{\circ} \mathrm{S}$ we have both a low $(21.0$ $\mathrm{Sv}$ ) and a high (28.2) value in October/November of different years, another low (19.4 Sv) value in March and a maximum (30.2 Sv) in June.

If a quasi-stationary Sverdrup transport cycle would result from seasonal wind forcing (e.g., Mayer and Weisberg 1993, their Fig. 6), one would expect an annual cycle of about $\pm 5 \mathrm{~Sv}$ (over the total depth range) with a northward maximum in August/September. For a barotropic response only a fraction of $1-2 \mathrm{~Sv}$ of this annual cycle would fall into the upper $1000 \mathrm{~m}$ and be lost in the measurement noise.

Analysis of TOPEX/Poseidon altimetry suggests a very small annual signal in the surface currents south of the equator (S. Arnault 1997, personal communication). Therefore we will not speculate on seasonality in our observations from south of the equator.

\section{b. The Equatorial Undercurrent}

The four $35^{\circ} \mathrm{W}$ sections show the EUC in different expressions (Fig. 14). It has its core closest to the surface, at <50 m depth, in June 1991 and March 1994, whereas in the fall surveys of 1990 and 1992 the core is located at $100-150 \mathrm{~m}$. The largest transport was measured at $35^{\circ} \mathrm{W}$ in spring 1991 , totalling $43.6 \mathrm{~Sv}$, compared to only about half that in the two fall surveys and in March 1994 (Table 4). The maximum in June 1991 contrasts sharply with the transport measured along the $31^{\circ} \mathrm{W}$ section (Fig. 1) about one week later, which yielded only $13 \mathrm{~Sv}$. It appears from comparison of the ADCP maps and sections (Figs. 6a, 14) that the discrepancy is partly due to temporal changes during the June 1991 survey, but partly it is the consequence of different physics working at $35^{\circ} \mathrm{W}$ and at $31^{\circ} \mathrm{W}$ when the sections were taken. During the equatorial crossing at $35^{\circ} \mathrm{W}$ the intertropical convergence zone was located close to the equator with weak and even westerly winds on the equator, while in the fall surveys of 1990 and 1992 the southeast trades were extending northward across equator. Hence, in fall the EUC was measured during typical EUC situations, whereas in spring 1991 there was no 
forcing for westward surface flow at the equator, leading to a shoaling of the thermocline and causing an equatorial jet. This behavior is in agreement with earlier findings of eastward equatorial surface currents in the western Atlantic in spring, both in observations (Richardson and Reverdin 1987) and in high-resolution model fields (Schott and Böning 1991). Because of the atypical situation of June 1991 with probably an eastward surface jet generated and superimposed on the EUC, we do not use this value for the mean EUC value in Table 4.

The near-surface situation on the equator in spring resembles the conditions in between the monsoons in the Indian Ocean, when westerly winds blow at the equator, causing a semiannual eastward surface jet. The difference to the other surveys is obvious where the transport above $\sigma_{\Theta}=24.5$ is only about $6.6 \mathrm{~Sv}$, whereas in June 1991 it is $20.8 \mathrm{~Sv}$ (Table 4).

On average, the layer $\sigma_{\Theta}=24.5-26.8$, of the EUC is dominantly supplied through the NBC retroflection. The combined current patterns, water masses, and transports indicate that about $11 \mathrm{~Sv}$ of its source waters originate in the NBUC south of $10^{\circ} \mathrm{S}$. That is the amount that passes from $10^{\circ} \mathrm{S}$ past $5^{\circ} \mathrm{S}$, then around Cape San Roque and is carried westward across $44^{\circ} \mathrm{W}$ by the NBC. Our eastward flow determination at $44^{\circ} \mathrm{W}$ is not satisfactory due to the high amount of variability there, but its mean corresponds approximately to what passes eastward in that layer across $35^{\circ} \mathrm{W}$. It appears that the $\sigma_{\Theta}$ $=24.5-26.8$ layer gains about 6-7 Sv in the eastward flowing branch (Table 1). This would indicate about $40 \%$ of the northern supply for that layer. Above $\sigma_{\Theta}=$ 24.5 , the EUC carries $6.6 \mathrm{~Sv}$ across $35^{\circ} \mathrm{W}$, only about half of what the NBC and retroflection transport in that layer at $44^{\circ} \mathrm{W}$.

The scatter of the EUC transports at $35^{\circ} \mathrm{W}$ does not yield sufficient evidence on the annual cycle of the EUC. The weak or even westerly winds in northern spring should cause an eastward surface anomaly during that season, as seen most drastically in the June 1991 transports (Fig. 14, Table 4). At the EUC layer, the CME model suggests an annual cycle with an eastward maximum in boreal fall (Schott and Böning 1991), but the other existing observational base is insufficient to support this.

\section{c. Retroflection and throughflow}

The Meteor surveys were focused on the South Atlantic inflow into the cross-equatorial NBC and covered the western boundary regime north of the equator only marginally, with the exception of the $44^{\circ} \mathrm{W}$ section that cut not only across the NBC but also across the NBC retroflection, thus allowing some conclusions on the throughflow of South Atlantic water that continues along the coast. Into this discussion we also include transports from the $44^{\circ} \mathrm{W}$ section of Wilson et al. (1994).

As Fig. 12 shows, strong currents exist also north of the immediate retroflection, and the net eastward flow across $44^{\circ} \mathrm{W}$ is thus dependent on the length of the available sections. All sections show different distributions of eastward and westward current cores. In Table 1 we have listed those eastward retroflection transports from our surveys and from the Wilson et al. (1994) section that follow immediately north of the NBC.

The March 1994 section along $44^{\circ} \mathrm{W}$ yielded an eastward retroflection transport of only $4.5 \mathrm{~Sv}$ above $\sigma_{\Theta}=$ 24.5, about $9 \mathrm{~Sv}$ below the northwestward NBC flow in that layer (Fig. 12d), whereas in the EUC layer, $\sigma_{\Theta}$ $=24.5-26.8$, the retroflection flow of $14.5 \mathrm{~Sv}$ exceeded the NBC inflow in that layer by about $3 \mathrm{~Sv}$. In the layer below $\sigma_{\Theta}=26.8$, the westward flow of $12.1 \mathrm{~Sv}$ was by far exceeded by an eastward current core of $28.7 \mathrm{~Sv}$.

For October 1992 it appears as if the retroflection for the EUC fraction above $\sigma_{\Theta}=24.5$ [which transported $4.7 \mathrm{~Sv}$ across $35^{\circ} \mathrm{W}$ (Fig. 14)] occurred east of $44^{\circ} \mathrm{W}$, because there is no eastward flow south of $4^{\circ} \mathrm{N}$ and also the water mass properties on $\sigma_{\Theta}=25.0$ (Fig. 9a) do not show southern water mass properties at $44^{\circ} \mathrm{W}$. Instead, the eastward flow north of $4^{\circ} \mathrm{N}$ supplied the NECC, with waters of mostly northern origin. In the $\sigma_{\Theta}$ $=24.5-26.8$ layer at $44^{\circ} \mathrm{W}$, there is a close correspondence between the westward NBC and eastward retroflection transport of $8 \mathrm{~Sv}$ - that is, the southern source waters of that layer are apparently completely returned into the EUC.

In June 1991 the NBC was at a transport low and the retroflection transport exceeded the NBC transport in all three layers considered. Water mass properties of that survey show a clear connection of the upper-layer NBC with the EUC at $35^{\circ} \mathrm{W}$, while part of the retroflection core in the layer $\sigma_{\Theta}=24.5-26.8$ gets directed into the NEUC. Water mass properties as well as the current vectors on $\sigma_{\Theta}=26.7$ show partial supply of the NEUC out of the NBC and thus by waters form the Southern Hemisphere (Fig. 6).

As already concluded by Schott et al. (1995) from the difference between the NBC and the retroflection transport combined with their water mass contrast, the upper-layer throughflow for March 1994 amounted to about $10 \mathrm{~Sv}$. It is now interesting to note that the alongshore flow of March 1996 (Fig. 7) is also about $12 \mathrm{~Sv}$ above $\sigma_{\Theta}=26.8$. These results suggest that in northern spring a direct throughflow along the boundary toward the Caribbean exists, as postulated earlier by seasonal high-resolution modeling results (Philander and Pacanowski 1986).

\section{d. The zonal intermediate currents}

The meridional sections along $35^{\circ} \mathrm{W}$ show a range of westward flow underneath the EUC (Fig. 14), identifying the Equatorial Intermediate Current (EIC). Its depth range and latitudinal extent varies from case to case. From the four surveys a mean transport of 22.1 \pm 9.8 Sv was obtained for the EIC (Table 5).

It is noteworthy that the EIC transport had a minimum 
TABLE 5. Trasnports of intermediate-depth currents (Sv) in western tropical Atlantic at $35^{\circ} \mathrm{W}$.

\begin{tabular}{ccccccc}
\hline \hline $\begin{array}{c}\text { Current } \\
\text { branch }\end{array}$ & Oct 1990 & Nov 1992 & Jun 1991 & Mar 1994 & Mean & Std. dev \\
\hline EIC & $-29.7^{\mathrm{b}}$ & -30.0 & -9.5 & -19.0 & $-22.1\left(-16.6^{\mathrm{c}}\right)$ & 9.8 \\
NICC & $\ldots$ & 4.8 & $21.1^{\mathrm{a}}$ & 9.8 & $11.9\left(8.5^{\mathrm{c}}\right)$ & 8.4 \\
SICC & 10.2 & 6.5 & 5.9 & 11.4 & $8.5^{\left(7.2^{\mathrm{c}}\right)}$ & 2.7 \\
\hline
\end{tabular}

a Equator to $2.3^{\circ} \mathrm{N}$.

b $2.5^{\circ} \mathrm{S}$ to $1.1^{\circ} \mathrm{N}$.

${ }^{\mathrm{c}}$ From composite flow field.

value $(9.5 \mathrm{~Sv})$ in June 1991 when the EUC had its strongest transport (43.6 Sv) among the cases studied, leading even to eastward currents at the AAIW core level (Fig. 10a) and that it had a maximum $(30.0 \mathrm{~Sv})$ in the November 1992 survey when the EUC had a low value $(19.5 \mathrm{~Sv})$. The EIC is embedded in between the eastward flowing Northern and Southern Intermediate Countercurrent at $1^{\circ}-3^{\circ}$ latitude. They carried mean transports for the four sections of $11.9 \pm 8.4 \mathrm{~Sv}$ and $8.5 \pm 2.7 \mathrm{~Sv}$, respectively.

As already pointed out by Schott et al. (1995), the water mass properties of the SICC relate it to AAIW source waters from the lower part of the NBUC. In our water mass classification of the other cruises (e.g., Figs. $10 \mathrm{a}, \mathrm{b})$, this pattern is confirmed. The southern part of the EIC also resembles these water mass properties, suggesting that it is supplied by SICC recirculation from the south. Our surveys also show a cruise to cruise variability in water mass distributions. While in November 1992 water of $>34.5 \mathrm{psu}$ and $>3.6 \mathrm{ml} \mathrm{l}^{-1}$ was occurring up to $1.5^{\circ} \mathrm{N}$ along the $35^{\circ} \mathrm{W}$ section and occupying the southern part of the $44^{\circ} \mathrm{W}$ section, it was limited to south of the equator in the other surveys (Fig. $10 \mathrm{~b})$.

The existence of these three zonal flow bands at the AAIW level is also confirmed by $800-\mathrm{m}$ level float tracks (W. Zenk 1997, personal communication). Floats drifting westward within the EIC, upon reaching the western boundary, would then veer northwestward along the boundary.

As for the upper-layer boundary inflow from the south, these patterns suggest a disruption of the AAIW propagation along the boundary, an excursion into the interior via the SICC and return westward by the EIC, with another loop introduced north of the equator by the NICC.

\section{Summary and conclusions}

The results of our WOCE surveys with R/V Meteor show a well-defined warm water inflow from the Southern Hemisphere into the western tropical boundary regime. The near-surface layer contribution (above the isopycnal $\sigma_{\Theta}<24.5$ ) of that inflow is supplied dominantly from the east, out of low-latitude sources through the South Equatorial Current, but its deeper part is supplied through the North Brazil Undercurrent from along the South American coast out of source waters located further south than $10^{\circ} \mathrm{S}$. In Fig. 15 we show the mean section currents from $10^{\circ} \mathrm{S}, 5^{\circ} \mathrm{S}, 35^{\circ} \mathrm{W}$, and $44^{\circ} \mathrm{W}$. The mean NBUC is seen in Fig. $15 \mathrm{a}, \mathrm{b}$. The $35^{\circ} \mathrm{W}$ mean section shows quite nicely the different mean current cores discussed in the previous sections. The transport numbers associated with those mean currents are lower than the means of Table 4 because there the averages over the current cores of the individual sections are taken, which move around among the surveys. There is no doubt now over the persistent existence of the various zonal undercurrents marked in Fig. 15c.

The most variable situation among the four sections of Fig. 15 was encountered at $44^{\circ} \mathrm{W}$ (Fig. 15d), and the mean from the ship sections shown here does not resemble as well a longer-term average as the presentations for the other sections. North of the NBC we find the retroflection with large transports reaching to $4^{\circ} \mathrm{N}$, and north of it again eastward flow, where the subsurface core corresponds to the NEUC.

Transports for the warm water inflow are schematically put together in Fig. 16, based on the means of Tables 1-5. Above $\sigma_{\Theta}=24.5$, less than $1 \mathrm{~Sv}$ arrive with the NBUC along the coast at $10^{\circ} \mathrm{S}$. Through SEC inflow from the east, this transport grows to $3.2 \mathrm{~Sv}$ at $5^{\circ} \mathrm{S}$. Across $35^{\circ} \mathrm{W}$, this upper-layer NBUC transport and additional SEC inflow combine to a joint westward transport of $11.3 \mathrm{~Sv}$ across $35^{\circ} \mathrm{W}$ and $10.8 \mathrm{~Sv}$ across $44^{\circ} \mathrm{W}$ (Fig. 16a). Hence, in this layer, less than $10 \%$ of the warm water inflow into the western equatorial boundary regime originates from south of $10^{\circ} \mathrm{S}$ along the coast (Fig. 16a). The retroflection mean total from four surveys amounts to $12.2 \mathrm{~Sv}$, which means that inflow out of the NEC recirculation has to be included at an amount matching the northwestward throughflow. In the $\sigma_{\Theta}=24.5-26.8$ layer, the northward transport at $10^{\circ} \mathrm{S}$ carries $10.6 \mathrm{~Sv}$, and only negligeable inflow joins from the east in the $10^{\circ}-5^{\circ} \mathrm{S}$ latitude belt (Fig. 16b). Across $35^{\circ} \mathrm{W}$, the total westward transport south of the equator in this layer is $16.5 \mathrm{~Sv}$; that is, $5.1 \mathrm{~Sv}$ join with the low-latitude SEC. Imbedded in this westward flow is the eastward-flowing SEUC with $1.9 \mathrm{~Sv}$, which is supplied out of recirculation. Hence the net transport toward the equator in that layer is $14.6 \mathrm{~Sv}$. At the $44^{\circ} \mathrm{W}$ section, only $11.8 \mathrm{~Sv}$ are observed, a loss of about 3 $\mathrm{Sv}$, which we will address below.

Below $\sigma_{\Theta}=26.8$, the deep NBUC delivers $10 \mathrm{~Sv}$, 

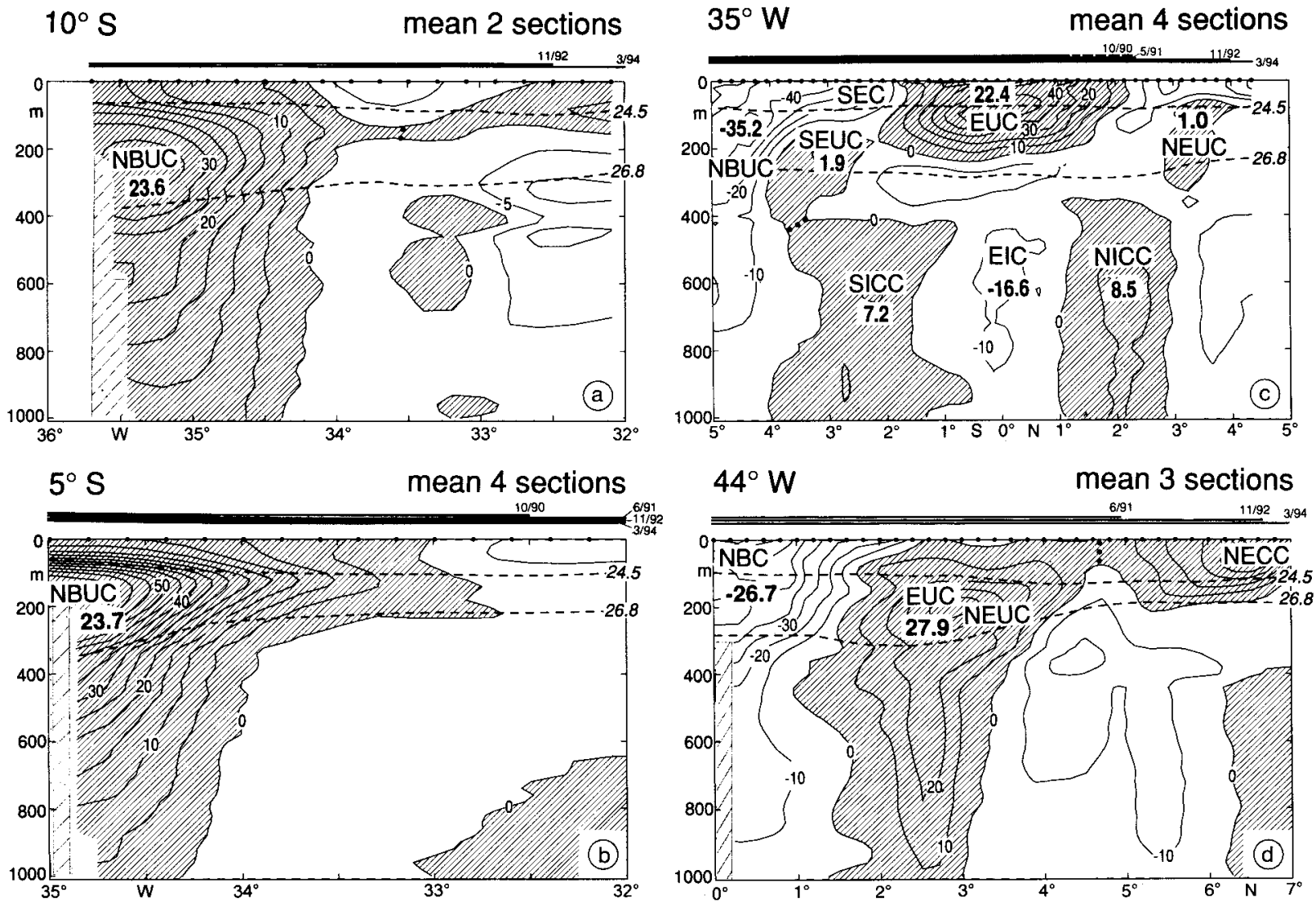

FIG. 15. Mean flow across the repeated sections, averaged over cruises as marked on top of each section, and all direct current observations (shipboard ADCP, LADCP, and Pegasus) for (a) $10^{\circ} \mathrm{S}$, (b) $5^{\circ} \mathrm{S}$, (c) $35^{\circ} \mathrm{W}$, and (d) $44^{\circ} \mathrm{W}$. Current cores as dicussed in the text are identified and total transports of cores in averaged sections are shown.

northward to the equatorial zone. An amount of 12.4 $\mathrm{Sv}$ crosses the $35^{\circ} \mathrm{W}$ meridian westward along the boundary. The eastward SEUC transport below $\sigma_{\Theta}=$ 26.8 (down to about $500 \mathrm{~m}$ ) is $2.6 \mathrm{~Sv}$ (Table 4). In that depth range there are also two other large intermediate currents south of the equator: the Southern Intermediate Countercurrent flowing eastward at depth about 400$1000 \mathrm{~m}$ in the latitude range $1^{\circ}-3^{\circ} \mathrm{S}$ and the Equatorial Intermediate Current, flowing westward below the EUC in the latitude range $2^{\circ} \mathrm{S}-2^{\circ} \mathrm{N}$ (Fig. 15c). The SICC mean from four surveys was $8.5 \pm 2.7 \mathrm{~Sv}$ (Table 5). Its water masses show it to draw out of the NBUC, as marked in Fig. 16c. The EIC has a large transport, of $22.1 \pm$ $9.8 \mathrm{~Sv}$, and part of this flow returns as the SICC. The deep NBC at $44^{\circ} \mathrm{W}$ carries $12.2 \mathrm{~Sv}$ westward, interacting in a still unresolved way with the EIC and NICC.

In the layer budget analysis between $35^{\circ} \mathrm{W}, 40^{\circ} \mathrm{W}$, and $35^{\circ} \mathrm{W}$ of the March 1994 survey, we found a loss of about $3 \mathrm{~Sv}$ out of the $\sigma_{\Theta}=24.5-26.8$ layer and about an equivalent gain in the surface layer and concluded on the possibility of upwelling between the layers. In the averages from the different surveys, a similar budget deficit appears in the second layer but no equivalent gain in the top layer; hence, upwelling does not seem to be an important factor in the mean boundary circulation. Instead, the undercurrent deficit could be caused by retroflection into the EUC east of the $44^{\circ} \mathrm{W}$ section (Fig. 16b), for which we saw evidence in part of our surveys.

As a means of comparing our observations of South Atlantic warm water inflow with those of earlier studies based on geostrophy (e.g., Schmitz and Richardson 1991; Schmitz 1995), we have also added (in Table 3) the transports across $10^{\circ} \mathrm{S}$ by standard temperature classes. At $24^{\circ} \mathrm{N} 29 \mathrm{~Sv}$ of water warmer than $7^{\circ} \mathrm{C}$ are transported by the Florida Current (e.g., Schmitz and Richardson 1991), and in the Antilles passages south of St. Lucia, Wilson and Johns (1997) recently measured an inflow of $9.1 \mathrm{~Sv}$ warmer than $7^{\circ} \mathrm{C}$. The rest of the Florida Current source waters stem either out of northern recirculation or out of waters from the South Atlantic that have made excursions through the equatorial current system toward more northern Caribbean passages. We find $15.2 \mathrm{~Sv}$ of water warmer than $7^{\circ} \mathrm{C}$ passing $10^{\circ} \mathrm{S}$ with the NBUC, but as discussed below, only a fraction of it continues directly along the Guiana boundary.

The along-boundary transfer occurs either as a more or less steady boundary current in boreal spring, ob- 

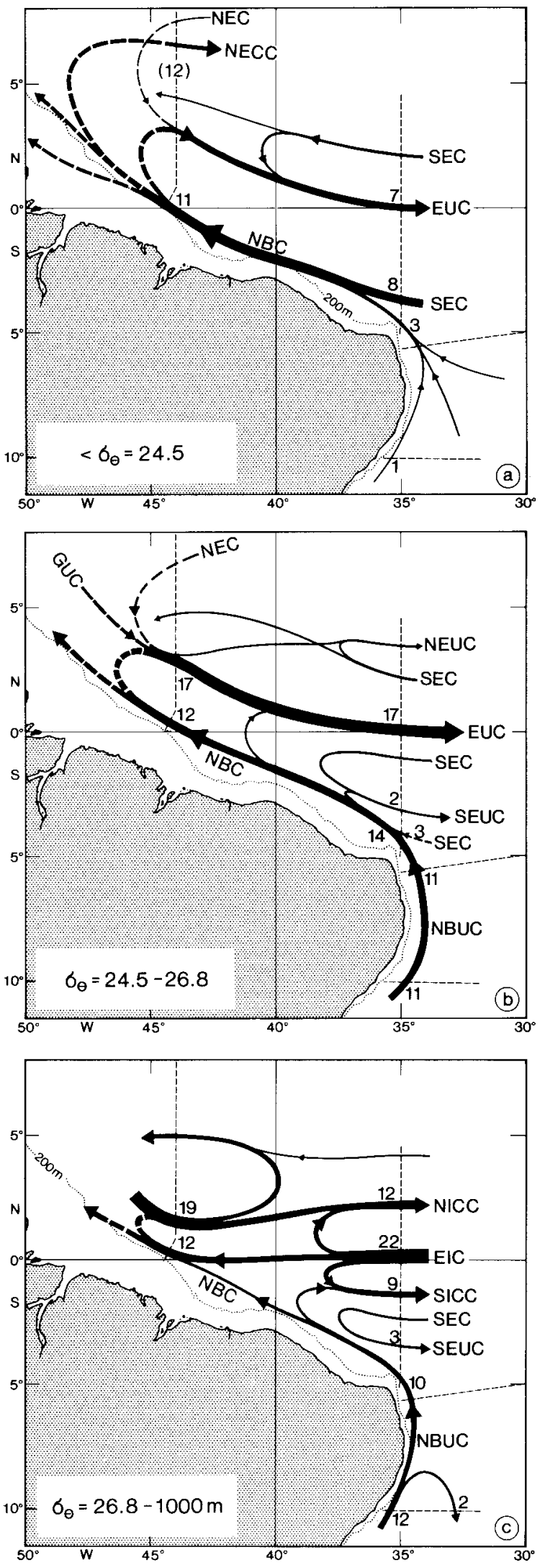

served with a transport of 10-12 Sv in both of our March surveys (Fig. 5, Fig. 7), or as a suite of large anticyclonic eddies that are shed from the retroflection zone during boreal fall and winter with an estimated upper-layer mean transport of 2-3 Sv (Didden and Schott 1993; Richardson et al. 1994). Taking the mean current as 10 $\mathrm{Sv}$ over three months (March-June) would result in an annual mean of $2.5 \mathrm{~Sv}$. Hence the total alongshore transfer of upper-level Southern Hemispheric waters above $\sigma_{\Theta}=26.8$ (or approximately above $10^{\circ} \mathrm{C}$ ) is then $5 \mathrm{~Sv}$. Below, some amount of AAIW transfer, significantly diluted by the zonal excursions via the intermediate currents, would have to be added, but that is outside of our observational domain. While at $44^{\circ} \mathrm{W}$ the transport over the shelf was found small, at $<1 \mathrm{~Sv}$, that contribution increases farther north where the shelf is somewhat deeper and wider to about $3 \mathrm{~Sv}$ at $4^{\circ} \mathrm{N}$ (Johns et al. 1998). This shelf excursion of the NBC is indicated in Fig. 16a.

As regards the supply of the zonal currents, the nearsurface flow connects with the NECC in boreal summer to fall (as shown in Fig. 9a), whereas in boreal spring the NEUC seems to be supplied out of the retroflection (Fig. 5b). For representativeness of the NECC and NEUC in the averaged circulation diagram (Fig. 16) it should be noted that the section coverage north of $3^{\circ} \mathrm{N}$ was sparse and that there might also be a seasonal bias of these branches in our surveys. Throughout the year, the bulk of the NBC thermocline flow is retroflected into the EUC (Fig. 16b). There is also inflow from the north into the NECC and EUC out of recirculating NEC waters; even at the northern flank of the EUC northern water mass properties are found. Below the surface, this inflow occurs via the Guiana Undercurrent, the equatorward branch of the northern-shallow tropical-subtropical cell (STC). At the AAIW level, there is obviously significant recirculation, involving the deep NBC, the eastward NICC, and the westward EIC.

The seasonal cycle of the NBC is small on the equator, only $\pm 2.5 \mathrm{~Sv}$, that is, of order $10 \%$ of the mean flow, but increases rapidly northward, to $\pm 12 \mathrm{~Sv}$ near $4^{\circ} \mathrm{N}$ (Johns et al. 1998). Part of this large variability is due to the seasonal migration of the retroflection zone; that is, it does not constitute a net northwestward transport change.

Regarding the disruption of the boundary flow north of the equator during most of the year, the tropical Atlantic shows similarities to the Somali Current except that the eddies there remain trapped in the area, probably due to the different meridional slopes of both coastal boundaries. The dynamics that prohibit an equatorial western boundary current from progressing northward

$\leftarrow$

FIG. 16. Schematic mean circulation diagram for (a) the near-surface layer $\sigma_{\Theta}<24.5$, (b) the undercurrent layer $24.5<\sigma_{\Theta}<26.8$, and (c) the AAIW layer $\sigma_{\Theta}=26.8-1000 \mathrm{~m}$; see text for details. 
along the coast much beyond the equator are based on potential vorticity conservation, as first pointed out for the Indian Ocean by Anderson and Moore (1979). For a northward cross-equatorial inertial flow over a quiet sublayer of constant inflow layer thickness the interface has to rise northward and finally intersect the surface; that is, the flow has to turn offshore. While this leads to low-latitude upwelling at the shallow shoulder of the offshore-turning Somali Current, coastal upwelling is not observed off Guiana.

High-resolution numerical model results (Schott and Böning 1991) show an almost total retroflection of the NBC into the NECC in northern summer and fall. In winter/spring when the NECC is not present in the model and the NECC region is covered by mesoscale eddies, there is still no continuous flow along the boundary in the CME model. Ongoing studies with that model in which Lagrangian tracers are seeded into the cross-equatorial flow, show that the particles in winter drift up along the coast a bit farther than in summer and then veer off into the interior where they then continue their way northward and enter the Caribbean through one of the northern passages (Kröger 1995, 1997, personal communication).

In summary, significant transport, far in excess of the amount of about $15 \mathrm{~Sv}$ required to close the Atlantic thermohaline cell (e.g., Schmitz and McCartney 1993), arrives with the North Brazil Current at the equator. So far, a clear distinction of the southern STC from the topto-bottom Atlantic Meridional Overturning Circulation has not been possible. A qualitative evaluation of highresolution Atlantic models, such as the CME or that of Philander and Pacanowski (1986) shows the zonally integrated STC circulation to be between 10 and $15 \mathrm{~Sv}$ (M. Hamann 1997, personal communication). How much of it passes through the model NBUC toward the equator and ends up in our boundary transport appears to be model dependent.

Overall, and based on the observational data discussed here, the fate of the South Atlantic waters after they arrive at the equator, and the role of the equatorial zone in modifying them and delaying their transfer from one hemisphere to the other, is still fairly obscure and requires future model and observational work. This is even more true for variability signals that arrive at the equator, that is, pulses of waters subducted during extreme winters in the subtropics or at subpolar latitudes. Further questions requiring answers are the effects of atmospherically imposed variability, such as related to ENSO events, on the cross-equatorial exchanges.

Acknowledgments. We thank the captain and crew of the R/V Meteor as well as C. Meinke and our technical group for their help with the field work. We further acknowledge the assistance of G. Krahmann and U. Garternicht in the data analysis and the drafting work of A. Eisele. We thank D. Wilson (NOAA/AOML) for permitting us use of his ADCP currents from the $44^{\circ} \mathrm{W}$ section of August 1989 and W. Johns (RSMAS, University of Miami) for allowing us to use his NBC transports from $4^{\circ} \mathrm{N}$. We also appreciate helpful discussions with B. Bourles and Y. Gouriou (ORSTOM/Brest), S. Arnault (ORSTOM/Paris), and M. Hamann (IFM Kiel). Financial support was received through the German WOCE program by the Bundesministerium für Bildung, Wissenschaft, Forschung und Technologie under Grant 03F0157A.

\section{REFERENCES}

Anderson, D. L. T., and D. V. Moore, 1979: Cross-equatorial inertial jets with special relevance to very remote forcing of the Somali Current. Deep-Sea Res., 26, 1-22.

Arnault, S., 1987: Tropical Atlantic geostrophic currents and ship drifts. J. Geophys. Res., 92 (C5), 5076-5088.

Bryden, H., and E. Brady, 1985: Diagnostic model of the threedimensional circulation in the upper layer Pacific Ocean. J. Phys. Oceanogr., 15, 1255-1273.

Csanady, G. T., 1987: What controls the rate of equatorial warm water mass formation? J. Mar. Res., 45, 513-532.

Didden, N., and F. Schott, 1992: Seasonal variations in the western tropical Atlantic: Surface circulation from Geosat altimetry and WOCE model results. J. Geophys. Res., 97 (C3), 3529-3541.

$\longrightarrow$, and — 1993: Eddies in the North Brazil Current retroflection region observed by Geosat altimetry. J. Geophys. Res., 98 (C11), $20121-20131$

Fischer, J., and M. Visbeck, 1993: Deep velocity profiling with selfcontained ADCPs. J. Atmos. Oceanic Technol., 10, 764-773.

Friedrichs, M. A. M., and M. M. Hall, 1993: Deep circulation in the tropical North Atlantic. J. Mar. Res., 57, 697-736.

Gordon, A., 1986: Interocean exchange of thermocline water. J. Geophys. Res., 91, 5037-5046.

Gouriou, Y., and G. Reverdin, 1992: Isopycnal and diapycnal circulation of the upper equatorial Atlantic Ocean. J. Geophys. Res., 97, 3543-3572.

Johns, W. E., T. N. Lee, F. Schott, R. J. Zantopp, and R. Evans, 1993: The North Brazil Current retroflection: Seasonal structure and eddy variability, J. Geophys. Res., 95, 22 103-22 120.

$\longrightarrow,-$ R. C. Beardsley, J. Candela, R. Limeburner, and B. Castro, 1998: Annual cycle and variability of the North Brazil Current. J. Phys. Oceanogr., 28, 103-128.

Levitus, S., 1982: Climatological Atlas of the World Ocean. NOAA Prof. Paper No. 13, U.S. Govt. Printing Office, 173 pp.

Liu, Z., S. G. H. Philander, and R. C. Pacanowski, 1994: A GCM study of tropical-subtropical upper-ocean water exchange. $J$. Phys. Oceanogr., 24, 2606-2623.

Lu, P., J. P. J. McCreary, and B. A. Klinger, 1998: Meridional circulation cells and the source waters of the Pacific Equatorial Undercurrent. J. Phys. Oceanogr., 28, 62-84.

Mayer, D. A., and R. H. Weisberg, 1993: A description of COADS surface meterological fields and the implied Sverdrup transports for the Atlantic Ocean from $30^{\circ} \mathrm{S}$ to $60^{\circ} \mathrm{N}$. J. Phys. Oceanogr., 23, 2201-2221.

McCreary, J. P. J., and P. Lu, 1994: Interaction between the subtropical and equatorial ocean circulations: The subtropical cell. J. Phys. Oceanogr., 24, 466-497.

Metcalf, W. G., and M. C. Stalcup, 1967: Origin of the Atlantic Equatorial Undercurrent. J. Geophys. Res., 72, 4959-4974.

Molinari, R. L., 1982: Observations of eastward currents in the tropical South Atlantic Ocean: 1977-1980. J. Geophys. Res., 87, 9707-9714.

— , and E. Johns, 1994: Upper layer temperature structure of the western tropical Atlantic. J. Geophys. Res., 99, 18 225-18 233.

Pedlosky, J., 1987: An inertial theory of the equatorial undercurrent. J. Phys. Oceanogr., 17, 1978-1985.

Philander, S. G. H., and R. C. Pacanowski, 1986: A model of the 
seasonal cycle in the tropical Atlantic Ocean. J. Geophys. Res., 91, 14 192-14 206.

Reid, J. L., 1964: Evidence of a South Equatorial Counter Current in the Atlantic Ocean in July 1963. Nature, 203, 182.

— 1989: On the total geostrophic circulation of the South Atlantic Ocean: Flow patterns, tracers, and transports. Progress in Oceanography, Vol. 23, Pergamon, 149-244.

Reverdin, G., R. F. Weiss, and W. J. Jenkins, 1993: Ventilation of the Atlantic Ocean equatorial thermocline. J. Geophys. Res., 98, $16289-16310$

Rhein, M., L. Stramma, and U. Send, 1995: The Atlantic deep western boundary current: Water masses and transports near the equator. J. Geophys. Res., 100, 2441-2457.

Richardson, P. L., and S. G. H. Philander, 1987: The seasonal variations of surface currents in the tropical Atlantic Ocean: A comparison of ship drift data with results from a general circulation model. J. Geophys. Res., 92, 715-724.

, and G. Reverdin, 1987: Seasonal cycle of velocity in the Atlantic North Equatorial Countercurrent measured by surface drifters, current meters and ship drifts. J. Geophys. Res., 92, 3691-3708.

_ and W. J. Schmitz, 1993: Deep cross-equatorial flow in the Atlantic measured with SOFAR floats. J. Geophys. Res., 98, $8371-8387$.

— G. E. Hufford, R. Limeburner, and W. S. Brown, 1994: North Brazil Current retroflection eddies. J. Geophys. Res., 99, 50815093.

Roemmich, D. H., 1983: The balance of geostrophic and Ekman transports in the tropical Atlantic Ocean. J. Phys. Oceanogr., 13, 1534-1539.

Schmitz, W. J. J., 1995: On the interbasis-scale thermohaline circulation. Rev. Geophys., 33, 151-173.

-, and P. L. Richardson, 1991: On the sources of the Florida Current. Deep-Sea Res., 38, 389-409.
— and M. S. McCartney, 1993: On the North Atlantic circulation. Rev. Geophys., 31, 29-49.

Schott, F., and C. Böning. 1991: The WOCE model in the western equatorial Atlantic: Upper layer circulation. J. Geophys. Res., 96, 6993-7004.

_ J. Jischer, J. Reppin, and U. Send, 1993: On mean and seasonal currents and transports at the western boundary of the equatorial Atlantic. J. Geophys. Res., 98, 14 353-14 368.

- L. L. Stramma, and J. Fischer, 1995: The warm water inflow into the western tropical Atlantic boundary regime, spring 1994. J. Geophys. Res., 100, 24 745-24 760.

Stammer, D., and C. Wunsch, 1994: Preliminary assessment of the accuracy and precision of TOPEX/Poseidon altimeter data with respect to the large scale ocean circulation. J. Geophys. Res., 99, 24 584-24 604.

Stramma, L., J. Fischer, and J. Reppin, 1995: The North Brazil Undercurrent. Deep-Sea Res., 42, 773-795.

Talley, L. D., 1996: Antarctic Intermediate Water in the South Atlantic. The South Atlantic-Present and Past Circulation, G. Wefer, W. H. Berger, G. Siedler, and D. J. Webb, Eds., SpringerVerlag, 219-238.

Tsuchiya, M., 1986: Thermostads and circulation in the upper layer of the Atlantic. Progress in Oceanography, Vol. 16, Pergamon, 235-267.

— 1989: Circulation of the Antarctic Intermediate Water in the North Atlantic Ocean. J. Mar. Res., 47, 747-755.

Wilson, W. D., and W. E. Johns, 1997: Velocity structure and transport in the Windward Island Passages. Deep-Sea Res., 44, 487-520.

— E. Johns, and R. L. Molinari, 1994: Upper layer circulation in the western tropical North Atlantic Ocean during August 1989. J. Geophys. Res., 99, 22 513-22 523.

Wunsch, C., 1984: An eclectic Atlantic Ocean circulation model. $J$. Phys. Oceanogr., 14, 1712-1733. 